\title{
Environmental and seasonal dynamics altering the primary productivity in Bingo-Nada (Bingo Sound) of the Seto Inland Sea, Japan
}

\author{
ShizUKa OHARA ${ }^{1}$, Ryoko YANO ${ }^{2}$, Etsuko Hagiwara ${ }^{3}$, Hiroyuki Yoneyama ${ }^{3} \&$ \\ KAZUHIKO KOIKE ${ }^{2, *}$ \\ ${ }^{1}$ Graduate School of Biosphere Science, Hiroshima University, 1-4-4 Kagamiyama, Higashi-hiroshima, Hiroshima 739-8528, \\ Japan \\ ${ }^{2}$ Graduate School of Integrated Sciences for Life, Hiroshima University, 1-4-4 Kagamiyama, Higashi-hiroshima, Hiroshima \\ 739-8528, Japan \\ ${ }^{3}$ Hiroshima Prefectural Agriculture, Forestry and Fisheries Bureau, 10-52 Motomachi, Naka-ku, Hiroshima 730-8511, Japan
}

Received 1 October 2019; Accepted 24 December 2019 Responsible Editor: Tetsuichi Fujiki

doi: $10.3800 /$ pbr. 15.78

\begin{abstract}
Monthly phytoplankton monitoring with primary productivity estimation using pulse amplitude modulation (PAM) fluorometry was conducted from May 2014 to March 2018 in Bingo-Nada, center of the Seto Inland Sea, Japan, where oligotrophication has been a concern. The average chlorophyll $a$ concentration, $7.24 \mu \mathrm{g} \mathrm{L}^{-1}$, was even higher than the values of previous studies; therefore, it should not be assumed that the primary productivity has decreased. However, some seasonal trends seemed to drastically change; one of them was notable diatom blooms from December to January. PAM fluorometry revealed that high $F v / F m$ of the diatoms due to rich nutrients and high $\alpha$ values (initial slope of ETR versus light) enabled them to actively photosynthesize even under low-light conditions in winter. This winter bloom further caused severe nutrient depletion in spring, which resulted in notable drops in overall photosynthesis and the ETR-based primary production rate $\left(\mathrm{PPR}_{\mathrm{ETR}}\right)$ in March or April. From May, $F v / F m$ and $\mathrm{rETR}_{\max }$, which be-

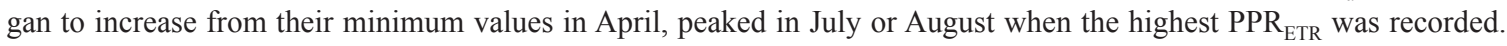
However, over $70 \%$ of the total phytoplankton population consisted of dinoflagellates, raphidophytes and silicoflagellates, not diatoms. The $\mathrm{PPR}_{\mathrm{ETR}}$ then drastically decreased from August to September, regardless of the fact that there were rich nutrients in the entire water column. Rather, decreased light level, as well as increased turbidity caused by non-phytoplankton particles, especially those abundant in this season, might hinder photosynthesis in autumn, further resulting in nutrient-rich conditions leading to the winter bloom.
\end{abstract}

Key words: diatoms, flagellates, pulse amplitude modulation (PAM) fluorometry, primary production, Seto Inland Sea

\section{Introduction}

The Seto Inland Sea (Fig. 1) is the largest semi-enclosed sea in Japan and is surrounded by three main islands, Honshu, Shikoku and Kyushu. This sea is connected to the outer waters of the Pacific Ocean and the Sea of Japan via three waterways, the Kii Channel, Bungo Channel and Kanmon Strait. The area of the Seto Inland Sea, which is scattered with more than 700 islands, is as large as

*Corresponding author: Kazuhiko Koike; E-mail, kazkoike@hiroshimau.ac.jp
$21,827 \mathrm{~km}^{2}$, and the average depth is as shallow as $37.2 \mathrm{~m}$. The coastline stretches $6,760 \mathrm{~km}$ long, is inhabited by $24 \%$ of the population of Japan, and has been well industrialized by heavy and chemical industries.

In the 1960s and early 1970 s, mostly due to the heavy industrialization and sewage dumping that continued until 1973, the sea, which suffered from heavy red tides in the 1970s, experienced heavy eutrophication (Yanagi \& Okaichi 1997). In 1973, the Interim Law for Conservation of the Environment of the Seto Inland Sea took effect, and in 1978, the Law Concerning Special Measures for Conservation of the Environment of the Seto Inland Sea was 


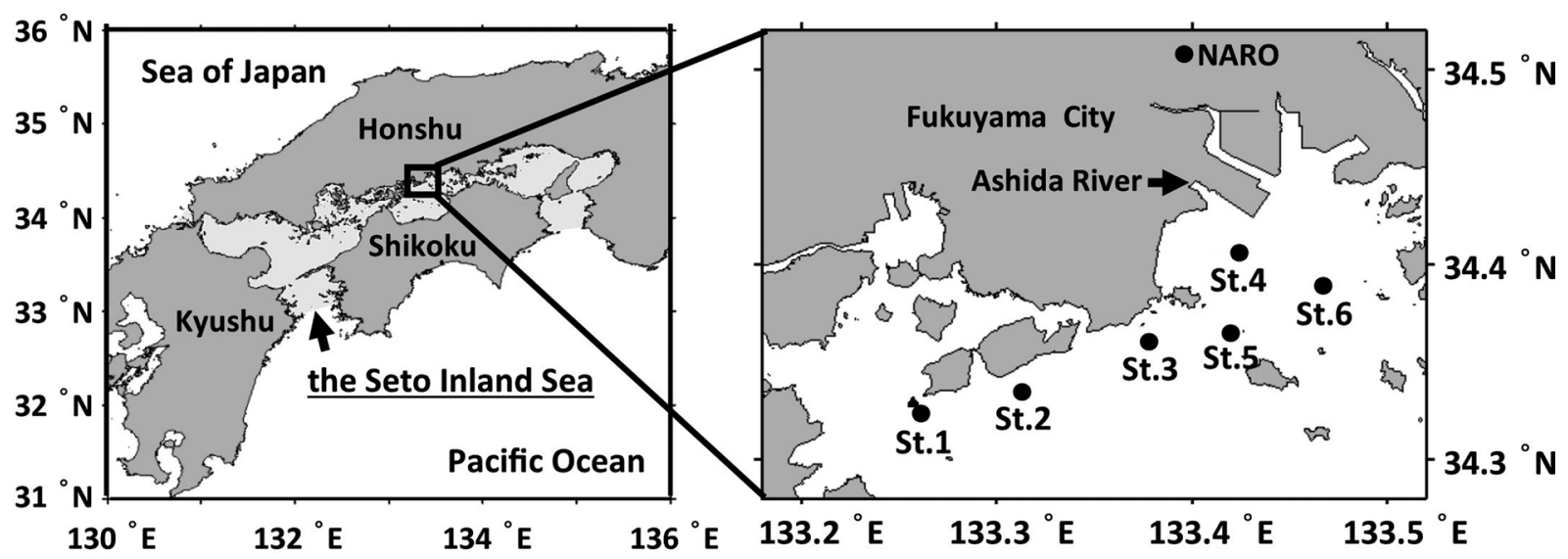

Fig. 1. A map of the sampling area and sampling stations in Bingo-Nada (Bingo Sound), the center of the Seto Inland Sea, Japan. The Western Region Agricultural Research Center of the National Agriculture and Food Research Organization (NARO), where global solar radiation data were obtained, is shown. The coast line data were obtained from the Ministry of Land, Infrastructure, Transport and Tourism (2019b).

enforced. Under this law, which initially called for a reduction in the chemical oxygen demand (COD) level and later (from the second half of the 1990s) called for decreases in the level of total nitrogen (TN), loadings of these elements to the sea have gradually been decreasing. The level of total phosphorus (TP) has sharply decreased in the first half of the 1980s (Abo \& Yamamoto 2019). These decreases in the nutrient levels resulted in an improvement in the number of red tide incidents from a maximum of 299 cases year ${ }^{-1}$ (in 1976) to approximately 100 cases year $^{-1}$ in recent years (Setonaikai Fisheries Coordination Office 2018a).

In response to these favorable effects of the law, ironically, "oligotrophication" of the sea has been a concern since approximately the 2000s (Yamamoto 2003), and in fact, the levels of dissolved nitrogen in the sea have been constantly decreasing (Tanda et al. 2014). From the 1970s to the 1980 s, the wild fish catch per unit area of the sea was reported to be an estimated 20.5 ton $\mathrm{km}^{-2}$ year ${ }^{-1}$, which was far above the catches in the Chesapeake Bay (6.5 ton $\mathrm{km}^{-2}$ year $^{-1}$ ), the North Sea $\left(5.7\right.$ ton $\mathrm{km}^{-2}$ year $^{-1}$ ), the Baltic Sea $\left(2.2\right.$ ton $\mathrm{km}^{-2}$ year $\left.{ }^{-1}\right)$ and the Mediterranean Sea (0.8 ton $\mathrm{km}^{-2}$ year $\left.{ }^{-1}\right)$ (Takeoka 1997). However, with oligotrophication, fish catches dropped from 485 thousand ton year $^{-1}$ in 1985 to almost one third that amount (157 thousand ton year ${ }^{-1}$ ) in 2016 (Setonaikai Fisheries Coordination Office 2018b). Such a decrease in catches likely involves diverse factors inhibiting local fisheries (e.g., lowered consumption and market prices of fishes and the avoidance of fisheries as a business in young generations); in addition, oligotrophication may hinder the biological production that used to prosper in the sea. Although there could be various factors influencing fish production, a strong link between primary production and yield of fish was empirically found at least for data at a broad scale (Nixon 1988).

Bingo-Nada, or Bingo Sound, is located in the center of the Seto Inland Sea. Bingo-Nada and Hiuchi-Nada, which is located at the south side of Bingo-Nada, are characterized by a low exchange rate with seawater from the outer ocean (Ueshima et al. 1985) and a relatively low supply of riverine TN and TP compared with other areas of the Seto Inland Sea (Yamamoto et al. 1996). Because seawater from the outer ocean has a minimal effect on Bingo-Nada, the sound is relatively sensitive to action from the land and/or humans. Inorganic nitrogen in the sound has obviously decreased, similar to the cases of other sounds or straits undergoing oligotrophication (Tanda et al. 2014). Our target study area off Fukuyama City was once an active fishing area, characterized by Nori (Pyropia seaweed) culture and wild fish catches (e.g., Japanese anchovy (Engraulis japonicus)). In Fukuyama City, since 1988, the Nori culture has been constantly decreasing, dropping from approximately 1.6 hundred million sheets year ${ }^{-1}$ to almost half of that level in recent years; similarly, the fish catch decreased from over 12,000 ton year ${ }^{-1}$ in 1982 to under 4,000 ton year ${ }^{-1}$ in recent years (Fukuyama City 2015). Based on the facts that the entire Seto Inland Sea has undergone oligotrophication and that Bingo-Nada is one of the most sensitive areas in the sea, receiving significant feedback from the land, it is plausible that the current oligotrophication and consequential environmental changes have reduced the productivity of the area. The current drastic changes in climate should also affect the mechanisms of productivity. However, the most recent investigations of primary productivity in the entire Seto Inland Sea were conducted in 1993 and 1994 (Tada et al. 1998), with occasional research in the Bisan Strait (e.g., Yamaguchi et al. 2015), and there has been a long-term gap in such studies from 1994 until now, although this period has experienced drastic environmental and climate changes. Therefore, to determine the most recent trends in the primary productivity of Bingo-Nada, we conducted monthly surveys from May 2014 to March 2018.

In our sampling strategy, the estimation of primary pro- 
ductivity by pulse amplitude modulation (PAM) fluorometry (Schreiber et al. 1986) was employed. Methodologies using the principle of carbon assimilation, originally the assimilation of ${ }^{14} \mathrm{C}$ (Steemann-Nielsen 1951), have been standard in primary productivity estimation and have been used in surveys in the Seto Inland Sea (e.g., Endo 1964, 1970, Uye et al. 1987). Because of limitations in using ${ }^{14} \mathrm{C}$ for carbon assimilation research, alternative methodologies using the stable isotope ${ }^{13} \mathrm{C}$ have been standardized in the sea (e.g., Tada et al. 1998, Yamaguchi et al. 2015). However, we did not employ this costly and labor-intensive methodology, because the aim of our study was to conduct frequent-long-term samplings at a site with relatively large horizontal and vertical environmental fluctuations, and to determine the environmental reasons (i.e., light, turbidity, nutrient levels, etc.) for alterations in productivity.

PAM fluorometry has recently been used to estimate primary productivity in coastal and freshwater areas (e.g., Goto et al. 2008, Napoléon \& Claquin 2012, Morelle et al. 2018). We incorporated a theory of Maung-Saw-HtooThaw et al. (2017) modified from Goto et al. (2008) and Napoléon \& Claquin (2012) in the present study. In their methodologies, the electron transport rate (ETR) from photosystem II (PSII) to downstream photosynthetic processes was estimated, and under the assumption that the transportation of a certain number of electrons $\left(\mathrm{e}^{-}\right)$produces 1 mol oxygen (principally $4 \mathrm{e}^{-}=1 \mathrm{~mol} \mathrm{O}_{2}$, but this value varies depending on physiological status) (Flameling \& Kromkamp 1998, Gilbert et al. 2000), both oxygen evolution and carbon assimilation could be estimated. PAM fluorometry provides information on the various statuses of photosystems, and a function of the Rapid Light Curve (RLC), which measures ETR under various light levels, provides a light versus ETR curve that is similar to (but not the same as) the so-called PI curve. Instantaneous measurement (within 4 min per single sample) of this RLC enables the estimation of light responses of phytoplankton communities exposed to different nutrient conditions at various depths and sampling sites. However, because PAM fluorometry does not measure carbon assimilation in dark reactions and measures only the electron transport from PSII, it does not indicate actual carbon incorporation; furthermore, even with the application of assumptions to PAM fluorometric estimates of carbon incorporation, this method tends to highly overestimate results compared to the ${ }^{14} \mathrm{C}$ or ${ }^{13} \mathrm{C}$ methods (Goto et al. 2008, Napoléon \& Claquin 2012, Maung-Saw-Htoo-Thaw et al. 2017). Therefore, in the current study, results based on PAM fluorometry were treated as relative values expressed as mol electron $\mathrm{m}^{-2} \mathrm{day}^{-1}$ of the water column. We employed this method to research fine details at different depths (3 depths per site) and sampling sites horizontally scattered over the study areas (4-6 stations) monthly for almost 4 years. This method also has the advantage of demonstrating alterations in photosynthetic responses in terms of ETR or RLC that respond well to in situ changes in various environmental factors (Cleveland \& Perry 1987, Geider et al. 1993, 1998, Lippemeier et al. 1999, 2001, Shelly et al. 2005, Higo et al. 2017).

Moreover, we did not simply discuss the phytoplankton biomass as chlorophyll $a$ concentration. Diatoms are the most important components of the phytoplankton community in terms of main primary production (Nelson et al. 1995); inversely, dinoflagellates and raphidophytes include species harmful for coastal fisheries, causing fish kills. Silicoflagellates are usually a minor component of the phytoplankton community but occasionally occur in high densities in the study area, and some species of silicoflagellates have been reported as harmful (Kawaguchi et al. 2007, Lømsland et al. 2013, Chang \& Mullan 2014). Therefore, in terms of the "quality" of primary producers, we investigated the occurrences of each phytoplankton taxa under a light microscope and, based on their cell volumes, estimated their contributions to the total phytoplankton occurrences.

Using these methodologies and concepts, at Bingo-Nada, which seems to be highly sensitive to current environmental changes, we aimed to clarify (1) the photosynthetic responses of phytoplankton communities under various light and nutrient conditions and possible environmental factors that led to alterations in these responses and resulting primary productivities, (2) the quality or contribution of each phytoplankton taxon, especially the flagellates group, and (3) possible recent changes in seasonality or environmental trends using a comparison with observations of past literature. Through this research, we ultimately aimed to clarify possible causes that may hinder local fisheries in order to improve the currently unfavorable situation.

\section{Materials and Methods}

\section{Sampling site and period}

Figure 1 shows a map of the sampling area in BingoNada (Bingo Sound), which is located off the coast of Fukuyama City, Hiroshima, Japan. The northeast side of the sampling site faces a Class A river under the criteria of the Ministry of Land, Infrastructure, Transport and Tourism, the Ashida River, which flows through Fukuyama City. The west side of the site faces numerous channels between islands and is affected by vertically mixing water that passes through the channels. A total of 6 stations was set; St. 1 and St. 2 were located on the western side of the study area and were greatly influenced by the channel water; St. 3 was in the middle of the study area; Sts. 4-6 were on the eastern side of the study area and affected by discharged water flowing from the Ashida River. The maximum depths at each station were $15.5 \sim 27.0 \mathrm{~m}$ at St. 1, $12.2 \sim 21.5 \mathrm{~m}$ at St. $2,9.0 \sim 11.9 \mathrm{~m}$ at St. 3, $4.7 \sim 10.6 \mathrm{~m}$ at St. $4,10.5 \sim 22.5 \mathrm{~m}$ at St. 5 and $13.0 \sim 17.5 \mathrm{~m}$ at St. 6 .

The typical climate in Japan exhibits distinct seasonal- 
ity, with spring, summer, autumn and winter. In this study, twelve months were operationally separated into spring (March, April and May), summer (June, July and August), autumn (September, October and November) and winter (December, January and February). Monthly field surveys were conducted principally at the 6 stations from May 2014 to March 2018, except during March 2015. St. 5 and St. 6 were occasionally skipped due to rough weather.

\section{Field sampling}

At each station, the vertical profiles of water temperature, salinity, dissolved oxygen and downward photosynthetic photon flux density (PPFD) were measured by sensors installed in a CTD (Hydrolab DS5, OTT HydroMet, Colorado, USA) at $0.5 \mathrm{~m}$ depth intervals. Sigma- $t$ was calculated using water temperature and salinity data measured with the CTD. Water samples from depths of 1,3 and 10 (or sea bottom-1) m were collected with a Van Dorn water sampler and subjected to chemical analyses (i.e., inorganic nutrients) or biological analyses (i.e., chlorophyll $a$ concentration, photosynthetic parameters and phytoplankton occurrence). In this sampling area, the surface layer from 0 to $2 \mathrm{~m}$ depth was greatly affected by riverine water from the Ashida River as well as significant stratification in summer; therefore, the water from $1 \mathrm{~m}$ depth was assumed to be representative for this layer. Meanwhile, from $2.5 \mathrm{~m}$ until $6.5 \mathrm{~m}$ depth, which was less affected by the riverine water and mostly within the euphotic layer, the water and phytoplankton population were relatively homogenous and thus represented by the water at $3 \mathrm{~m}$ depth. For water deeper than $6.5 \mathrm{~m}$, the water from $10 \mathrm{~m}$ depth, which was the middle depth of the center station (St. 2), was representative.

\section{Dissolved inorganic nutrients analysis}

Dissolved inorganic nitrogen (DIN; $\mathrm{NO}_{3}+\mathrm{NO}_{2}+\mathrm{NH}_{4}-$ $\mathrm{N}), \mathrm{PO}_{4}-\mathrm{P}$ and $\mathrm{SiO}_{2}-\mathrm{Si}$ were analyzed with a nutrient autoanalyzer (SWAAT, BLTEC, Tokyo, Japan) using water samples filtered through a syringe filter (25AS045AN, Advantec, Tokyo, Japan). Vertically collected water samples from 1, 3 and $10 \mathrm{~m}$ (or bottom-1 m) were used throughout whole samplings; in addition, water samples deeper than $10 \mathrm{~m}$ were collected at $5 \mathrm{~m}$ depth intervals to the seafloor from April 2017 to March 2018 and these were subjected to nutrient analysis.

\section{Chlorophyll $a$ concentration measurements}

In total, $100 \mathrm{~mL}$ samples of the water collected from 1 , 3 and $10 \mathrm{~m}$ (or the bottom-1 m) depth were filtered through glass microfiber filters (1825-025, Whatman International, Kent, UK); each filter was then soaked in $N, N$-dimethylformamide (Suzuki \& Ishimaru 1990) to extract chlorophyll $a$. The measurement was conducted fluorometrically according to Holm-Hansen et al. (1965) using a fluorometer (10 AU, Turner Designs, California, USA).

\section{Optical parameters}

The average PPFD ( $\mu \mathrm{mol}$ photons $\left.\mathrm{m}^{-2} \mathrm{~s}^{-1}\right)$ above the sea surface $\left(\mathrm{PPFD}_{\text {air }}\right)$ for every one hour (e.g., from 9:00AM to 10:00AM, 10:00AM to 11:00AM) was determined using the following equation:

$$
\begin{aligned}
\operatorname{PPFD}_{\text {air }} & \left(\mu \mathrm{mol} \text { photons } \mathrm{m}^{-2} \mathrm{~s}^{-1}\right) \\
= & \text { hourly global solar radiation }\left(\mathrm{MJ} \mathrm{m}^{-2} \mathrm{~h}^{-1}\right) \\
& \times 10^{6} \times 0.47 \times 4.57 / 3600
\end{aligned}
$$

where the hourly global solar radiation (from sunrise to sunset) measured at the Western Region Agricultural Research Center of the National Agriculture and Food Research Organization (NARO, Fig. 1) was averaged for the month when the field survey was conducted, and it was assumed that the PPFD in sunlight is equivalent to approximately $47 \%$ of the global solar radiation (Takami 2011). In addition, a coefficient of 4.57 was used to convert the global solar radiation to the photon flux density (Thimijan \& Heins 1983).

The monthly averaged PPFD ( $\mu$ mol photons $\mathrm{m}^{-2} \mathrm{~s}^{-1}$ ) below the sea surface $\left(\mathrm{PPFD}_{\text {surface}}\right)$ for every one hour was obtained by multiplying the monthly averaged $\mathrm{PPFD}_{\text {air }}$ by 0.85 , based on an assumption that $15 \%$ of PPFD is attenuated when passing through the sea surface (Parsons et al. 1984). The PPFD data obtained by the CTD were semi-log plotted against the water depth $(z)$, and a diffuse attenuation coefficient of the water column $(k)$ was determined according to Maung-Saw-Htoo-Thaw et al. (2017), with the assumption that turbidity of the water column was homogenous.

\section{Photosynthetic parameters}

To estimate primary productivity, pulse amplitude modulation (PAM) fluorometry, which instantaneously estimates the ETR $\left(\mu \mathrm{mol}\right.$ electron $\left.\mathrm{m}^{-2} \mathrm{~s}^{-1}\right)$ in the PSII of plants at various photon flux density levels, was used. The procedure principally followed the protocol reported by Maung-Saw-Htoo-Thaw et al. (2017). Briefly, sample water was collected from 1, 3, 10 or the bottom-1 m depth, kept for at least 30 minutes in the dark, subjected to measurements with a cuvette-type PAM fluorometer (Water-PAM, Heinz Walz, Effeltrich, Germany), and relative values of ETR (rETR) at eight actinic light levels $(158,241,356,553$, $825,1179,1648$ and $2743 \mu \mathrm{mol}$ photons $\mathrm{m}^{-2} \mathrm{~s}^{-1}$ for $30 \mathrm{sec}-$ onds) were obtained. Prior to exposure to the light series, a minimum $(F o)$ and a maximum $(F m)$ fluorescence under dark acclimation were measured and used to calculate the maximum photosynthetic yield under dark conditions $(F v / F m)$. The rETR versus light curve was fitted to the following model formula based on Platt et al. (1980):

$$
\begin{aligned}
\mathrm{rETR}= & \mathrm{rETR}_{\mathrm{mPot}} \times\left(1-\exp \left(-(\alpha \times \mathrm{I}) / \mathrm{rETR}_{\mathrm{mPot}}\right)\right) \\
& \times \exp \left(-(\beta \times \mathrm{I}) / \mathrm{rETR}_{\mathrm{mPot}}\right)
\end{aligned}
$$


where $\alpha$ is the initial slope of the rETR curve versus light, $\beta$ is the photoinhibition parameter, but is occasionally zero when photoinhibition does not occur, $\mathrm{rETR}_{\mathrm{mPot}}$ is the maximum value of rETR, assuming that there is no photoinhibition, and I is the level of actinic light. These parameters, $\mathrm{rETR}_{\mathrm{mPot}}, \alpha$ and $\beta$, were applied using the solver function of Microsoft Office Excel 2016. Then, the maximum relative electron transport rate, $\mathrm{rETR}_{\max }$, was calculated using the following equation (Platt et al. 1980):

$$
\operatorname{rETR}_{\max }=\operatorname{rETR}_{\text {mPot }} \times(\alpha /(\alpha+\beta)) \times(\beta /(\alpha+\beta))^{\beta / \alpha}
$$

Using the above described models, the rETR values at every $0.5 \mathrm{~m}$ of depth were determined by inputting the monthly averaged PPFD for every one hour at the corresponding depth $\left(\mathrm{PPFD}_{\mathrm{depth}}\right)$ into the following formula:

$$
\operatorname{PPFD}_{\text {depth }}(z \mathrm{~m})=\operatorname{PPFD}_{\text {surface }} \times \mathrm{e}^{-k \times z}
$$

The rETR versus light model for $1 \mathrm{~m}$ was used for every $0.5 \mathrm{~m}$ of depth between 0 and $2 \mathrm{~m}$; the model for $3 \mathrm{~m}$ was used for depths ranging from 2.5 to $6.5 \mathrm{~m}$; and the model for $10 \mathrm{~m}$ was used for depths ranging between $7 \mathrm{~m}$ to the euphotic layer.

rETR was converted to a chlorophyll $a$ (chl. a)-specific electron transport rate (ETR) using the following formula:

$$
\begin{aligned}
& \operatorname{ETR}\left(\mu \mathrm{mol} \text { electron mg chl. } a^{-1} \sec ^{-1}\right) \\
& \quad=\operatorname{rETR} \times 0.768 \times a^{*},
\end{aligned}
$$

where the value of 0.768 is the ratio of absorbed photons allocated to PSII. During our surveys, diatoms were the most dominant phytoplankton and the average absorption value of 0.768 was therefore used according to Johnsen and Sakshaug (2007). The chlorophyll $a$ (chl. $a$ )-specific absorption coefficient $\left(a^{*}\right)$ was determined with the glassfiber filter technique (Goto et al. 2008, Napoléon \& Claquin 2012) but only for the waters of $3 \mathrm{~m}$ depth at St. 1 and St. 4 from June 2014 to March 2016, and of $3 \mathrm{~m}$ depth at all stations from April 2016 to March 2018. By using these 152 data points in total, and the equation of $a^{*}\left(\mathrm{~m}^{2} \mathrm{mg}\right.$ chl. $\left.a^{-1}\right)=0.028 \times\left(\mathrm{chl} . a\left(\mathrm{mg} \mathrm{m}^{-3}\right)\right)^{-0.450}$ was determined following Bricaud et al. (1995), and was applied for other sample waters. Note that $a^{*}$ could be different between phytoplankton species or nutrient conditions (Napoléon et al. 2013).

The obtained ETR values ( $\mu$ mol electron mg chl. $a^{-1}$ $\mathrm{sec}^{-1}$ ) at each $0.5 \mathrm{~m}$ depth were converted to hourly values ( $\mu$ mol electron mg chl. $a^{-1}$ hour ${ }^{-1}$ ) by multiplying by 3600 , and daily ETR values ( $\mu$ mol electron mg chl. $a^{-1}$ day $^{-1}$ ) were obtained by integrating the hourly values from 0:00 to 24:00. The daily ETR value at each $0.5 \mathrm{~m}$ depth was then divided by the chlorophyll $a$ concentration (mg chl. $a$ in $1 \times 1 \times 0.5 \mathrm{~m}^{-3}$ ) and integrated from $0 \mathrm{~m}$ to the compensation depth to determine ETR-based daily primary production rates of the water column $\left(\mathrm{PPR}_{\mathrm{ETR}}\right)$ (mol electron $\mathrm{m}^{-2}$ day $^{-1}$ ). To obtain the compensation depth, the daily ETR value at each $0.5 \mathrm{~m}$ depth was temporarily converted to the gross oxygen evolution rate $(\mathrm{Pg})$ by multiplying with conversion rates of 0.117 (below $500 \mu$ mol photons $\mathrm{m}^{-2} \mathrm{~s}^{-1}$ ) or 0.073 (above $500 \mu \mathrm{mol}$ photons $\mathrm{m}^{-2} \mathrm{~s}^{-1}$ ) (Goto et al. 2008), and the respiration rate (R) was subtracted from these oxygen evolution rates to find the depth showing $\mathrm{Pg}=\mathrm{R}$. To estimate the $\mathrm{R}$, an assumption derived from the data set of Iriarte et al. (1991) was used; $\mathrm{R}(\mu \mathrm{mol} \mathrm{O}$ $\left.\mathrm{L}^{-1} \mathrm{~h}^{-1}\right)=0.0375 \times$ chl. $a\left(\mu \mathrm{g} \mathrm{L}^{-1}\right)+0.0877$. In this study, the compensation depth was from 2.0 to $16.5 \mathrm{~m}$, and the mean was $6.7 \mathrm{~m}$.

\section{Microscopic observations of phytoplankton and estima- tion of their biomass}

Water samples collected from depths of 1, 3 and 10 (or bottom-1) $\mathrm{m}$ were subjected to microscopic observations of phytoplankton and the estimation of phytoplankton biomass. A portion of the water sample was fixed with glutaraldehyde at a final concentration of $1 \%$, and diatom identification and cell counting were conducted for a total of $1 \mathrm{ml}$ of the fixed sample. Non-fixed sample water was used for counting other phytoplankton. For each observed species, cell sizes for at least 30-50 cells were measured under the microscope, and the cell volumes were determined according to Kovala \& Larrance (1966). The cell volumes were then converted to carbon contents using conversion factors for diatoms and non-diatoms (Strathmann 1967).

\section{Statistical analysis}

The means of the following six parameters were obtained by averaging the monthly values over four years: water column chlorophyll $a$ concentrations, PPR $_{\mathrm{ETR}}$, chlorophyll $a$-normalized primary production rates, and two optical parameters (i.e., $\mathrm{PPFD}_{\text {surface }}$ and $k$ ) and three photosynthetic parameters (i.e., $F v / F m, \mathrm{rETR}_{\max }$ and $\alpha$ ). To produce a box graph, the medians, first quartiles and third quartiles of the above six parameters were calculated using Microsoft Office Excel 2016. Significance differences $(p<0.05)$ between the monthly means of the above six parameters were examined with a Tukey-Kramer test followed by one-way analysis of variance (ANOVA) using $\mathrm{R}$ version 3. 5. 1 (R Core Team 2018) and were shown as different alphabetical letters above the graphs of Fig. $2 \mathrm{a}-2 \mathrm{~h}$.

\section{Results}

\section{Chlorophyll $a$ concentration}

Figure 2a shows the chlorophyll $a$ concentrations in the water columns, with each column representing data collected throughout the whole sampling period (left graph) or the averaged values of different months (right graph) over 4 years. While not statistically significant, chlorophyll $a$ was generally high from summer to autumn, July through October. Interestingly, the values again peaked in winter 
in January. The chlorophyll $a$ values were notably lowest in the spring, from March to May, regardless of the consensus that a spring bloom occurs in temperate regions. November was also a month when low chlorophyll $a$ values were observed.

\section{ETR-based daily primary production rate of the water column}

Figure $2 \mathrm{~b}$ shows the ETR-based daily primary production rate $\left(\mathrm{PPR}_{\mathrm{ETR}}\right)$. In the left graph, the production rate generally depicts a trend similar to the chlorophyll $a$ graph, indicating that production rates in the water column were mostly influenced by the phytoplankton biomass. However, this was not the case for the data from January to March. In this season, the lowest production rate was in January, while a notable chlorophyll $a$ peak was observed, and the production rate increased, until March (Fig. 2b left graph, gray parts) along with a decrease in chlorophyll $a$. This seemingly contradictory trend was also observed in the right graph, which shows averaged values for each month. In Fig. $2 b$ in the left graph, the production rate dropped once in April, increased from May and peaked during May through September. The rate then decreased from its peak; notable drops were observed from August to September in 2014 and 2017, from September to October in 2015 and from July to September in 2016 (Fig. 2b left graph, arrows). Such decreases continued and reached minima during October through December. The averaged values for each month (Fig. $2 \mathrm{~b}$ right graph) clearly depicted a production peak in August and a minimum in November. An exceptional peak in October 2016 was observed with a very high chlorophyll $a$ peak (Fig. $2 \mathrm{a}$ and $2 \mathrm{~b}$ left graphs, daggers).

\section{Chlorophyll $a$-normalized primary production rate}

Because the above PPR $R_{\text {ETR }}$ values were primarily controlled by phytoplankton biomass, PPR $_{\mathrm{ETR}}$ values normalized by the integrated chlorophyll $a$ concentration from the sea surface to the compensation depth were determined (Fig. 2c). In the left graph, the average rates (the line) from September to February, except for in October 2015, were almost always lower than the average of the whole sampling period (horizontal dotted line), and those from April through August, except for in July and August 2014, were normally higher than the whole average. In the right graph, twelve months were divided statistically into three periods: the period from April to August, with high production rates, and the period from December to February, with low production rates. March and September through November were transition months between the two periods.

\section{Optical parameters}

The factors largely controlling the primary production rate, other than chlorophyll $a$, are optical parameters and are shown in Figs. $2 \mathrm{~d}$ and $2 \mathrm{e}$. PPFD $_{\text {surface }}(\mu \mathrm{mol}$ photons $\mathrm{m}^{-2} \mathrm{~s}^{-1}$ ) was expressed as a daily value (mol photons $\mathrm{m}^{-2} \mathrm{~d}^{-1}$; daily $\mathrm{PPFD}_{\text {surface }}$ ) for comparison with the daily production rate. For the daily $\operatorname{PPFD}_{\text {surface }}$ (Fig. $2 \mathrm{~d}$ left graph), the monthly averaged values were roughly above the average of the whole sampling period (horizontal dotted line) from March to August and below the average from October to February. In the right graph (monthly values over the entire sampling period), the bars were statistically categorized to a period from April to August with higher daily PPFD $_{\text {surface }}$ and another from October to February with lower PPFD. March and September were a transient period that connects the lower PPFD season and the higher PPFD season.

For another optical parameter, $k$, the values from September to January were almost always higher than the whole average, while they dropped once in November or December (Fig. 2e left graph). The maximum monthly average was recorded in October and the lowest in March (Fig. 2e right graph).

\section{Photosynthetic parameters}

Together with the above described parameters (e.g., phytoplankton biomass and optical parameters), parameters relating to photosynthetic activity also influenced the production to a large extent.

Seasonally, the highest values of $F v / F m$ and $\alpha$ (initial slope of the rETR curve versus light) were recorded in winter, that is, December and January (Fig. $2 \mathrm{f}$ and $2 \mathrm{~h}$ right graph), but this high photosynthetic activity did not lead to an increase in the production rate because of the low $\mathrm{PPFD}_{\text {surface }}$ in winter (Fig. 2d right graph). In February, $\mathrm{Fv} / \mathrm{Fm}$ and $\alpha$ started to decrease, reaching their seasonal minima in April (Fig. $2 \mathrm{f}$ and $2 \mathrm{~h}$ right graph). $\mathrm{rETR}_{\max }$ showed a similar trend to $F v / F m$ and $\alpha$; it decreased beginning in January and reached a minimum in April (Fig. $2 \mathrm{~g}$

Fig. 2. Monthly values throughout the entire sampling period (from May 2014 to March 2018; left graph) and the averaged values for each month (right graph) of the chlorophyll $a$ concentration in the water columns (a), ETR-based daily primary production rate in the water columns (b), chlorophyll $a$-normalized primary production rate (c), monthly averaged daily value of photosynthetic photon flux density (PPFD) at the sea surface (daily $\left.\operatorname{PPFD}_{\text {surface}}\right)(\mathrm{d})$, diffuse attenuation coefficient (e), maximum quantum yield of photosystem II $(F v / F m$, f), maximum relative electron transport rate $\left(\mathrm{rETR}_{\max }, \mathrm{g}\right)$ and initial slope of the rETR curve versus light $(\alpha, \mathrm{h})$. Graphs of $(\mathrm{d})$ were constructed based on the hourly global solar radiation obtained in the Western Region Agricultural Research Center of the National Agriculture and Food Research Organization (NARO, Fig. 1b). The plots of (a), (b), (c) and (e) show values of the whole water columns at each sampling station, the plots of (f), (g) and (h) show values of each depth at the sampling stations. Gray parts, arrows and daggers in the left graphs were noted and discussed in the text. Alphabetical letters above the right graphs indicate a significant difference among months $(p<0.05$, one-way ANOVA followed by Tukey-Kramer test). Some over-scaled data plots in the months indicated by * are not shown in graph areas but were incorporated in the average calculation. 
(a) chlorophyll a concentration
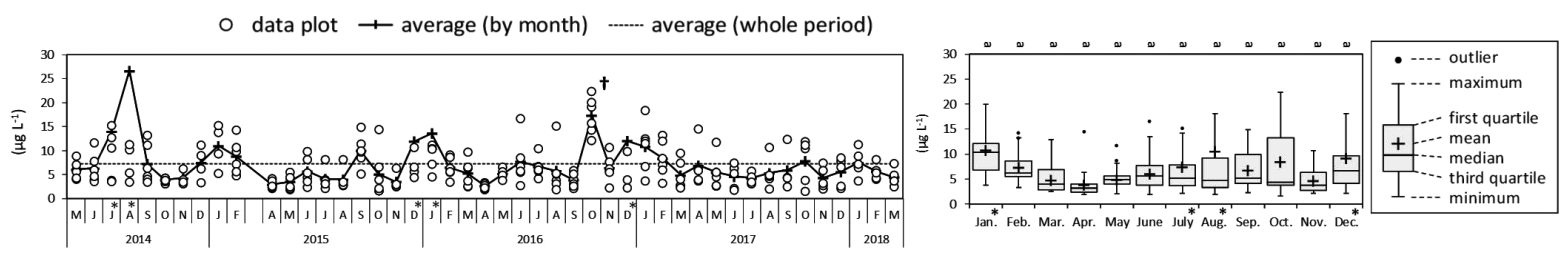

(b) ETR-based daily primary production rate (PPR ETR $_{\text {ET }}$
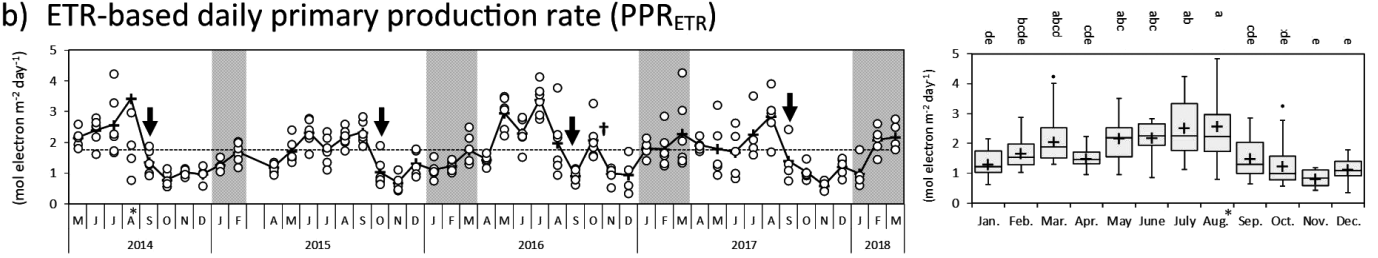

(c) chlorophyll a-normalized primary production rate
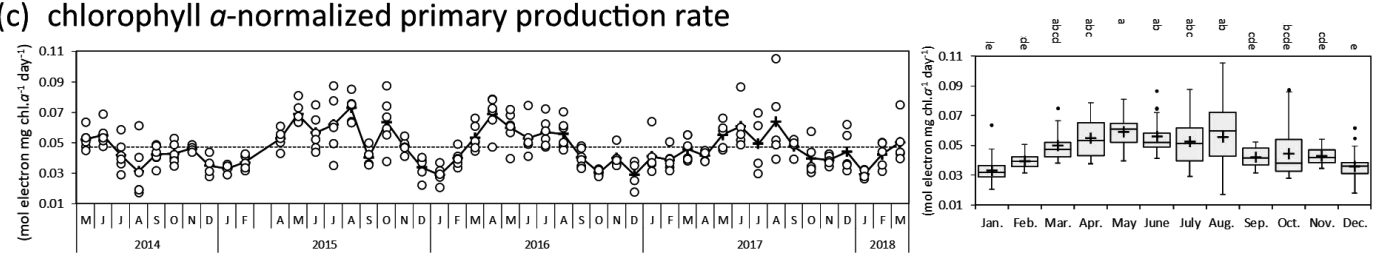

(d) daily PPFD surface
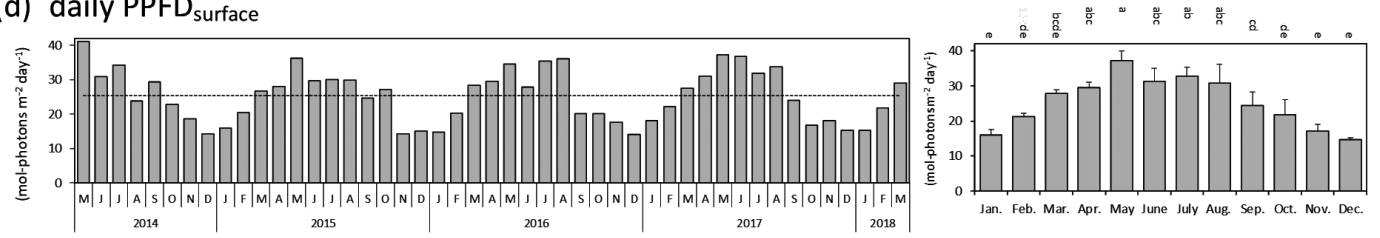

(e) diffuse attenuation coefficient ( $k$ )
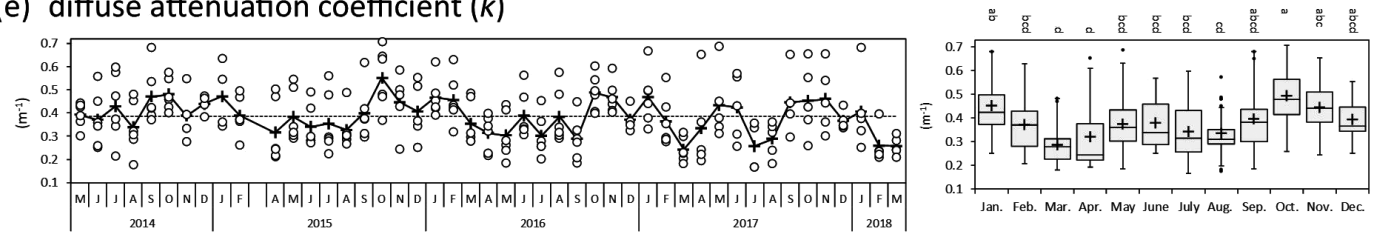

(f) maximum quantum yield ( $F v / F m)$
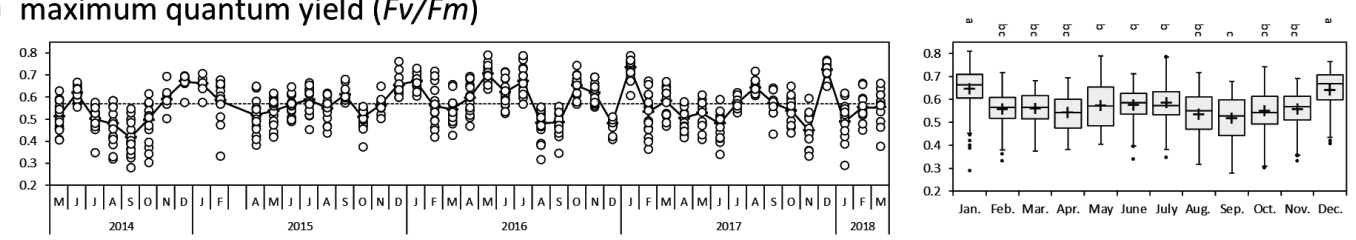

(g) maximum relative electron transport rate $\left(\mathrm{rETR}_{\max }\right)$
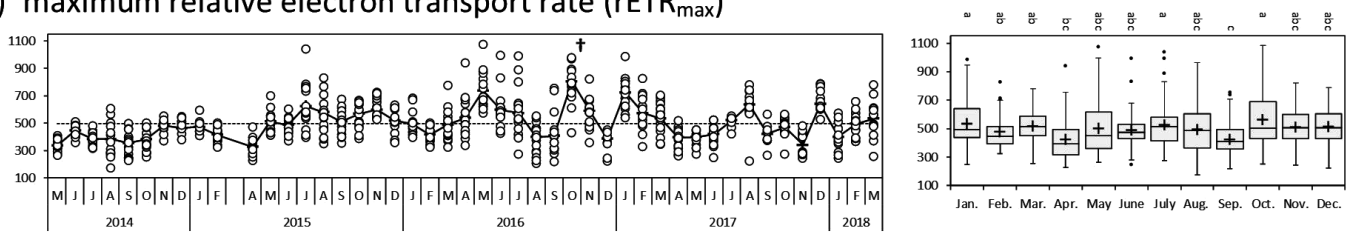

(h) initial slope of rETR curve versus light $(\alpha)$
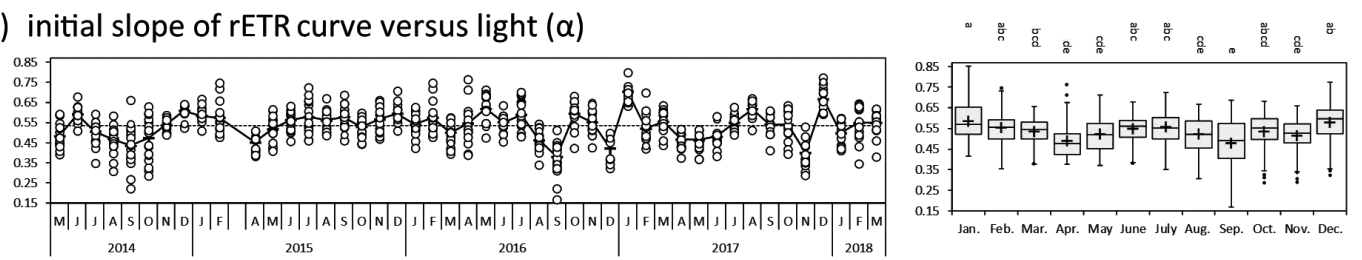
(a) water temperature $\left({ }^{\circ} \mathrm{C}\right)$
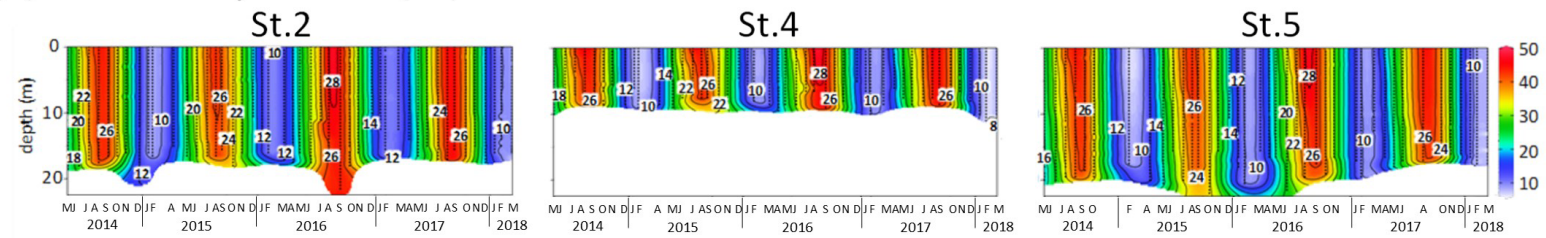

(b) salinity (PSU)
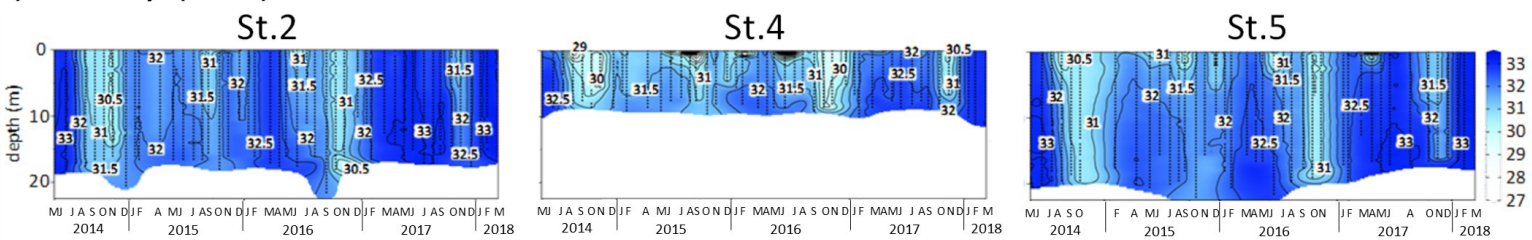

(c) sigma-t
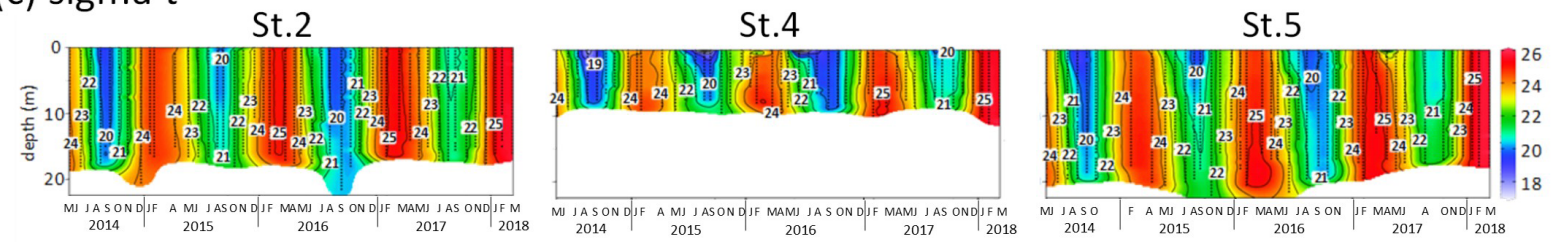

(d) dissolved oxygen (mg L-1)
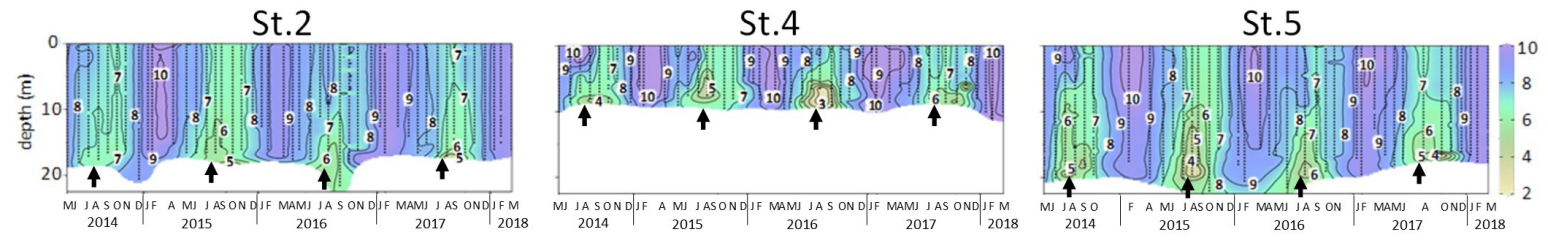

(e) DIN; $\mathrm{NO}_{3}+\mathrm{NO}_{2}+\mathrm{NH}_{4}-\mathrm{N}\left(\mu \mathrm{mol} \mathrm{L} \mathrm{L}^{-1}\right)$
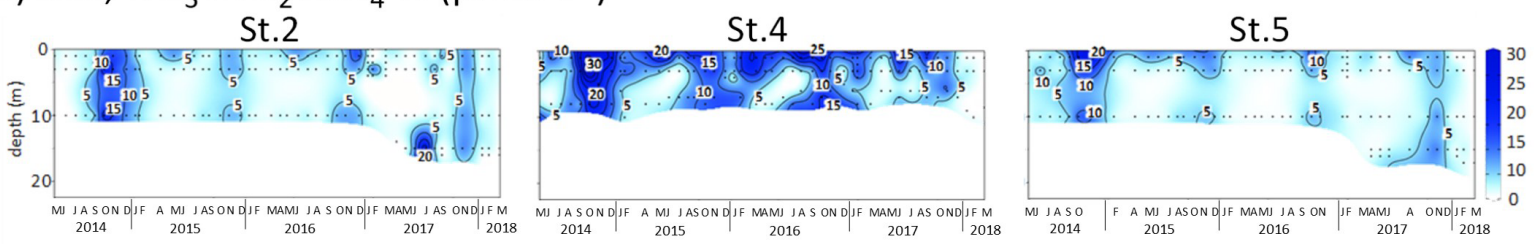

(f) $\mathrm{PO}_{4}-\mathrm{P}(\mu \mathrm{mol} \mathrm{L}-1)$
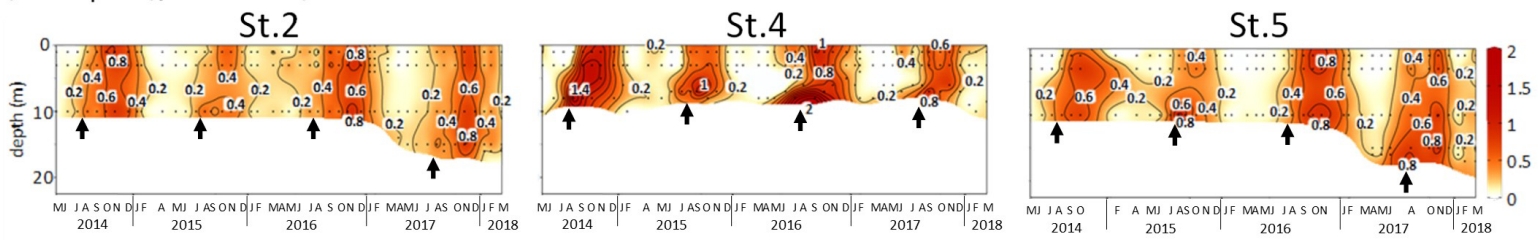

(g) $\mathrm{SiO}_{2}-\mathrm{Si}\left(\mu \mathrm{mol} \mathrm{L}^{-1}\right)$

St.2

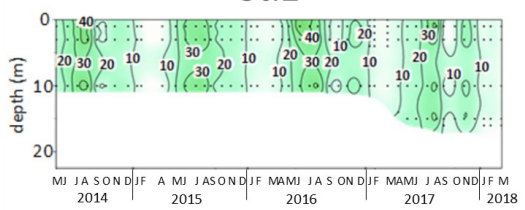

St.4

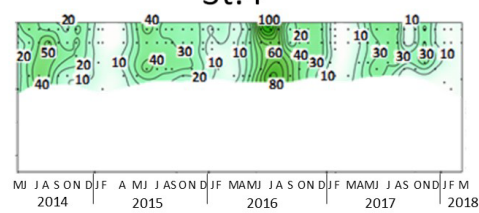

St.5

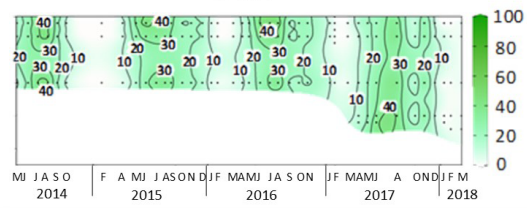

Fig. 3. Temporal vertical distributions of water temperature (a), salinity (b), sigma- $t$ (c), dissolved oxygen (d), DIN: $\mathrm{NO}_{3}+\mathrm{NO}_{2}+\mathrm{NH}_{4}-$ $\mathrm{N}(\mathrm{e}), \mathrm{PO}_{4}-\mathrm{P}$ (f) and $\mathrm{SiO}_{2}-\mathrm{Si}$ (g) at St. 2 (far west side), St. 5 (far east side) and St. 4 (near the Ashida River) throughout the sampling period (from May 2014 to March 2018). Monthly field surveys were conducted principal at the 6 stations during the sampling period, except in March 2015. And St. 5 was occasionally skipped due to rough weather. Arrows in the graphs were noted and discussed in the text. The figures were produced using Ocean Data View (Schlitzer 2018). 
(a) DIN/PO $-\mathrm{P}$ ratio (N/P ratio)
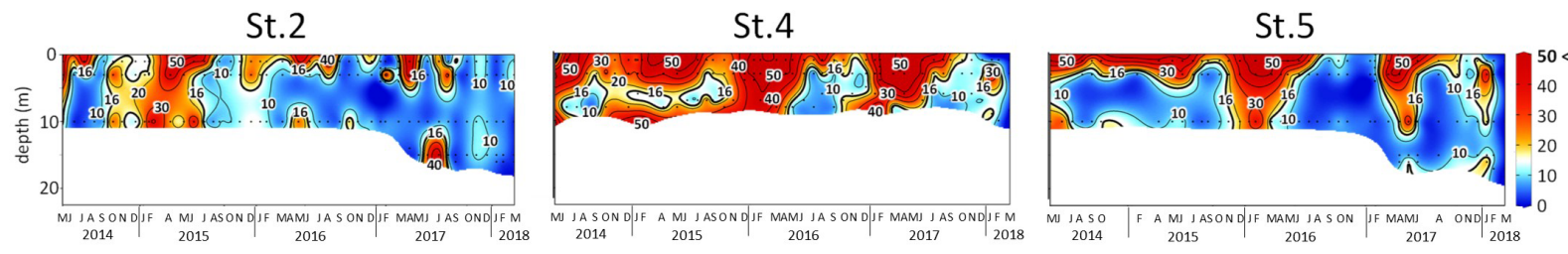

(b) $\mathrm{DIN} / \mathrm{SiO}_{2}-\mathrm{Si}$ ratio (N/Si ratio)
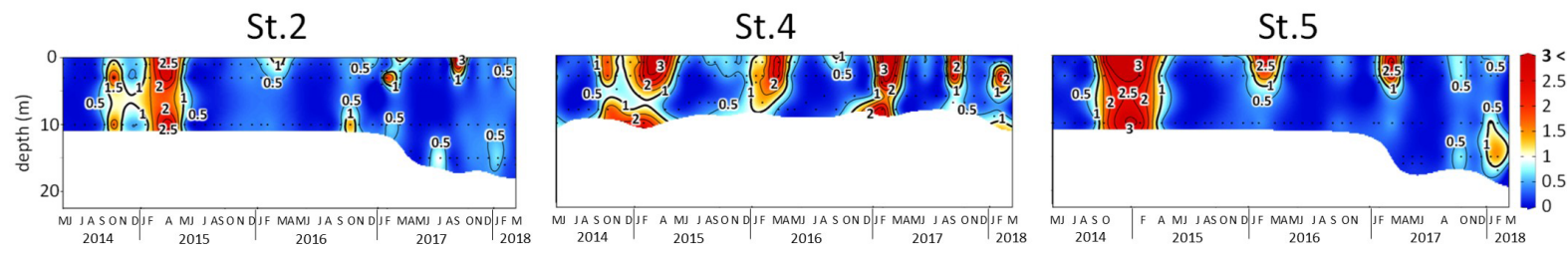

Fig. 4. Temporal vertical distributions of $\mathrm{DIN} / \mathrm{PO}_{4}-\mathrm{P}$ ratio (N/P ratio) (a) and $\mathrm{DIN} / \mathrm{SiO}_{2}-\mathrm{Si}$ ratio (N/Si ratio) (b) at St. 2 (far west side), St. 5 (far east side) and St. 4 (near the Ashida River) throughout the sampling period (from May 2014 to March 2018). Monthly field surveys were conducted principal at the 6 stations during the sampling period, except in March 2015. Thick solid line indicates N/P=16 or N/Si=1. And St. 5 was occasionally skipped due to rough weather. The figures were produced using Ocean Data View (Schlitzer 2018).

right graph). In the following season, from May to August, these photosynthetic parameters began to increase from their minimum values in April, peaked in July (Fig. $2 \mathrm{f}-\mathrm{h}$ right graph), and then decreased in September. These drops in the photosynthetic parameters in April and September were notable features of the current findings and caused significant decreases in the ETR-based daily primary production rate (Fig. $2 b$ right graph). Subsequently, after September, increases in $F v / F m$ and $\alpha$ were observed until December or January, during which they reached their annual peaks (Figs. $2 \mathrm{f}$ and $2 \mathrm{~h}$ right graph).

\section{Physiochemical parameters}

Figures $3 \mathrm{a}-\mathrm{g}$ show water temperature (a), salinity (b), sigma- $t$ (c) and dissolved oxygen (d), as well as DIN (e), $\mathrm{PO}_{4}-\mathrm{P}$ (f) and $\mathrm{SiO}_{2}-\mathrm{Si}(\mathrm{g})$, at the candidate sites of St. 2, St. 4 and St. 5, which represent the west, north and east sides of the sampling area respectively. Note that St. 4 was closest to the mouth of the Ashida River, the only major inflowing river in this area.

In the contour graph showing the seasonal and vertical distributions of salinity (Fig. 3b), salinity began to decrease notably beginning in the rainy season of June and July. The lowest salinities were usually recorded in October, when the autumn rain front dominated, and highest salinities were recorded in March through May (Fig. 3b). Levels of inorganic nutrients, i.e., DIN (Fig. 3e), $\mathrm{PO}_{4}-\mathrm{P}$ (Fig. 3f) and $\mathrm{SiO}_{2}-\mathrm{Si}$ (Fig. 3g), seemingly coincided with salinity; the levels of all nutrients were lowest in March or April, while DIN and $\mathrm{PO}_{4}-\mathrm{P}$ were highest in October, and $\mathrm{SiO}_{2}-\mathrm{Si}$ was highest in July. Consequently, nutrient loadings to the sampling area were primarily attributed to riverine water, mainly from the Ashida River.

DIN and $\mathrm{PO}_{4}-\mathrm{P}$ levels were highest in October and remained at high concentrations until December. From
January to April, all nutrient species, including $\mathrm{SiO}_{2}-\mathrm{Si}$, drastically decreased, and reached their minimum values in March or April. From May to August, DIN increased sporadically at $1 \mathrm{~m}$ depth due to the inflowing of riverine waters, but remained at a low concentration in the deeper layer. Both DIN and $\mathrm{PO}_{4}-\mathrm{P}$ again increased from September in the whole water column (Fig. 3e-f).

The mean of the DIN/ $\mathrm{PO}_{4}-\mathrm{P}$ ratio (N/P ratio) throughout the whole period for all stations was 57.2 \pm 265.1 (mean $\pm \mathrm{SD}$ ), showing sever phosphorus depletion. Especially at St. 4 near the mouth of the Ashida River, where much nitrogen sources are supplied, the N/P ratio was as high as 104.2 \pm 419.8 . At St. 2 and St. 5, higher N/P ratios could be observed in the surface layers, however, the ratio decreased to $11.9 \pm 19.8$ in the deeper layers in July and August (Fig. 4a). The mean of the $\mathrm{DIN} / \mathrm{SiO}_{2}-\mathrm{Si}$ ratio (N/Si ratio) was $0.7 \pm 1.5$, indicating silicon was not the limiting factor for diatoms, but from January to March, the ratio increased to $1.3 \pm 2.5$ in the surface layers, probably due to diatom consumption (Fig. 4b).

The bottom environment in summer seemed to contribute to the $\mathrm{PO}_{4}-\mathrm{P}$ supply; in July and August, $\mathrm{PO}_{4}-\mathrm{P}$ increased mainly in deep layers (Fig. 3f, arrows) due to excretion in the near-bottom ocean layer, and this often causes anoxic conditions (Fig. 3d, arrows) in stratified water (Fig. 3a-c), and temporarily relieves phosphorus depletion in this layer (Fig. 4a).

\section{Phytoplankton occurrences}

Figure 5 shows averaged proportions of each phytoplankton taxon based on biomass (estimated total carbon based on the cell density and cell size) determined for every sampling station and three depths.

Throughout the whole sampling period, the proportions of each phytoplankton taxon were; $54.0 \%$ diatoms, $21.8 \%$ 


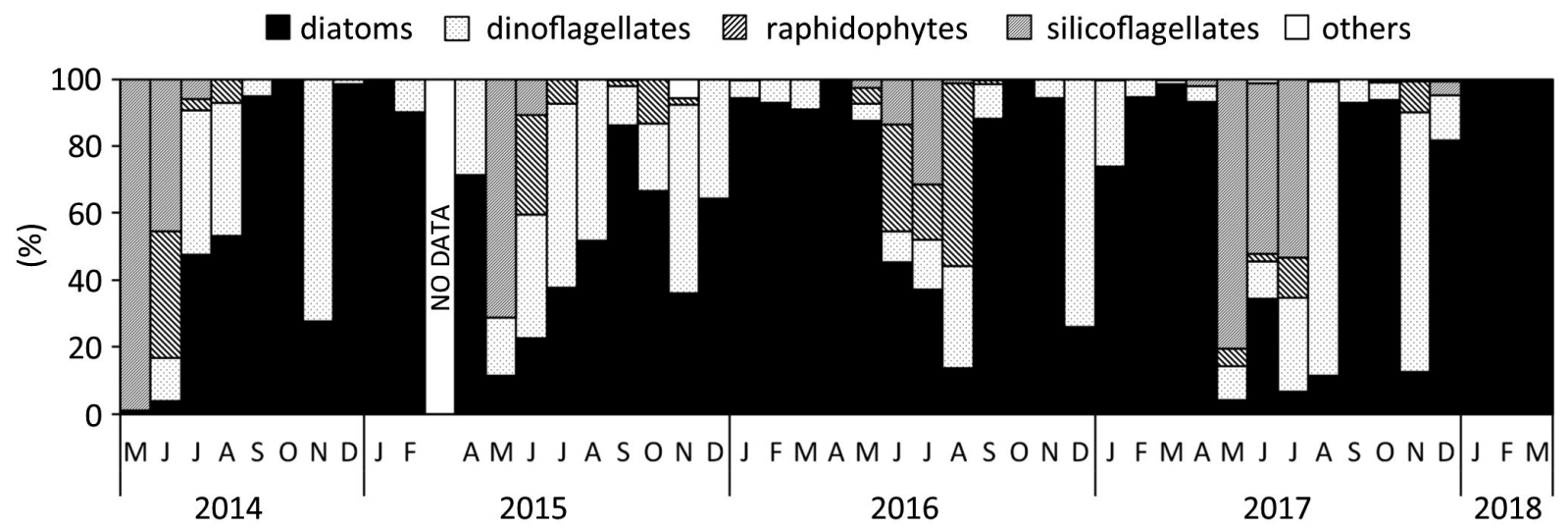

Fig. 5. Biomass (carbon equivalent) proportions of each phytoplankton taxon, estimated by their cell density and size, throughout the entire sampling period (from May 2014 to March 2018) determined for every sampling station and three depths.

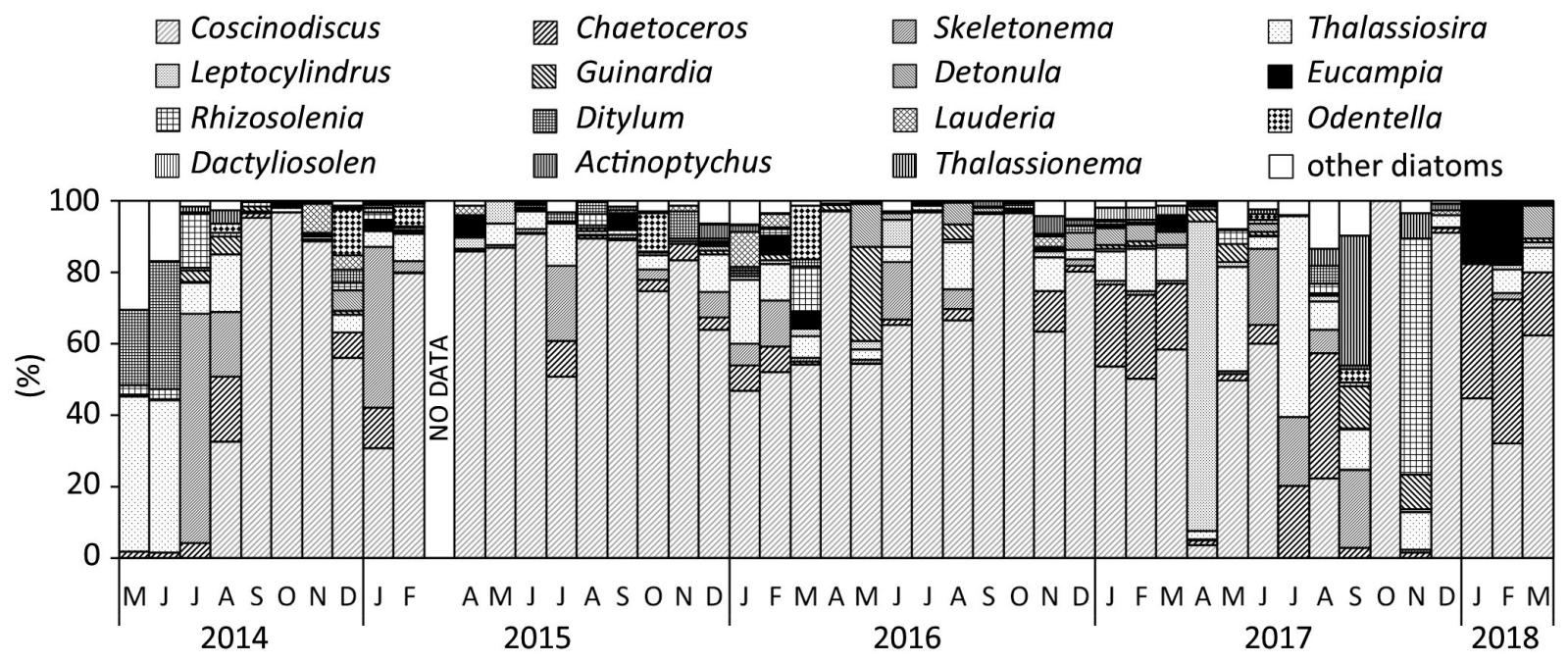

Fig. 6. Biomass (carbon equivalent) proportions of each diatom genus, estimated by their cell density and size, throughout the whole sampling period (from May 2014 to March 2018) determined for every sampling station and three depths. Only the top 15 genera are shown in the figure, and other genera are included in "other diatoms."

dinoflagellates, $16.4 \%$ raphidophytes, $7.8 \%$ silicoflagellates and $0.1 \%$ others, revealing that diatoms were the most dominant primary producers. Especially in the diatomdominated period, from January to April, the diatom component often accounted for over $90 \%$ of the population. The chlorophyll $a$ peaks observed in January (Fig. 2a left graph) almost completely consisted of diatoms (86.8\%).

During the high primary productivity period, May through August, the proportions of diatoms, dinoflagellates, raphidophytes, silicoflagellates and others were $23.6 \%, 23.4 \%, 35.9 \%, 17.2 \%$ and $0.02 \%$, respectively, and that of flagellates (dinoflagellates, raphidophytes and silicoflagellates) was $76.4 \%$, which was higher than the annual average $(46.0 \%)$. In addition, the proportion of diatoms decreased from the whole average of $54.0 \%$ to $23.6 \%$. Among the flagellates, silicoflagellates were almost completely Vicicitus globosus (former Chattonella globosa) (99.2\% of total silicoflagellate occurrence). The average proportion of $V$. globosus was $31.1 \%$ from May to July and decreased to $0.2 \%$ in August. The proportion of raphidophytes was $13.3 \%$ from May to August and increased to $16.9 \%$ from June to August. Among those raphidophytes, the genus Chattonella (C. antiqua, C. marina and C. ovata) was the dominant group (83.6\% of the total raphidophytes occurring from May to August). Another species of raphidophyte, Heterosigma akashiwo, was not a major component at our sampling site and bloomed only in June 2016, reaching a maximum cell density of 1,008 cells $\mathrm{mL}^{-1}$. Following diatoms, dinoflagellates made the second greatest contribution to the phytoplankton occurrence. From May to August, the genus Ceratium was the most dominant group ( $46.1 \%$ of the total dinoflagellate occurrence). The average proportion of the genus from May to August was $14.2 \%$. The second largest dinoflagellate contributor was Karenia mikimotoi, which represented $27.3 \%$ of all dinoflagellates from May to August and $34.6 \%$ of all dinoflagellates from July to August. The average proportion of the species from July to August was $16.2 \%$. K. mikimotoi 
bloomed and formed a red tide at St. 4 in July 2014 and St. 1 in August 2014, with a maximum cell density of 1,080 cells $\mathrm{mL}^{-1}$ (August 2014).

In seasons other than summer, diatoms were the main component of the phytoplankton population. Figure 6 shows the averaged biomass proportions (carbon equivalent) of each diatom genus, which were estimated by their cell density and cell size. A total of 29 genera and 66 species were recorded in this study. Coscinodiscus (Fig. 6) was the dominant genus throughout all seasons, because this genus has the largest cell size of the diatoms. October had the greatest relative proportions of Coscinodiscus, which represented $48.5-96.5 \%$ of all diatoms. The second largest chlorophyll $a$ peak in the whole sampling period was in October 2016 (Fig. 2a left graph, a dagger) and almost entirely consisted of Coscinodiscus wailesii. The genus Chaetoceros (Fig. 6) was the second largest group and appeared throughout the year. A total of 18 Chaetoceros species were found in this study, making Chaetoceros the most diverse genus. The third largest group of diatoms was the genus Skeletonema (Fig. 6). Skeletonema bloomed in summer and was dominant in August 2014 and 2017. The highest recorded chlorophyll $a$ concentration (Fig. 2a left graph, $91.19 \mu \mathrm{g} \mathrm{L}^{-1}$ ) throughout the whole sampling period was attributed to a Skeletonema red tide at St. 4 in August 2014.

\section{Discussion}

In this study, the primary production rates were expressed as ETR-based, not carbon assimilation-based, because we did not determine a carbon/ETR ratio $(\mathrm{C} /$ ETR ratio). By incorporating the range of C/ETR ratios reported by Goto et al. (2008), 0.053 to 0.176 determined at Lake Biwa, the primary production rates in this study were within $0.22 \sim 16.55 \mathrm{gC} \mathrm{m}^{-2} \mathrm{day}^{-1}$, an average of $2.41 \pm 1.92 \mathrm{gC} \mathrm{m}^{-2} \mathrm{day}^{-1}$. Meanwhile, based on a formula that converts ETR to carbon assimilation by Napoléon \& Claquin (2012), the rates of our study were as small as $0.13 \sim 0.19 \mathrm{gC} \mathrm{m}^{-2} \mathrm{day}^{-1}$, an average of $0.16 \pm 0.01 \mathrm{gC} \mathrm{m}^{-2} \mathrm{day}^{-1}$. Therefore, it might be inadequate to compare the current primary productivity estimates with those of the past, e.g., $0.08 \sim 0.8 \mathrm{gC} \mathrm{m}^{-2} \mathrm{day}^{-1}$ in 1979 and 1980 (Uye et al. 1987), or $0.3 \sim 0.7 \mathrm{gC} \mathrm{m}^{-2} \mathrm{day}^{-1}$ in 1993 and 1994 (Tada et al. 1998). Note that, however, the average value of chlorophyll $a$ concentration in this study, $7.24 \mu \mathrm{g} \mathrm{L}^{-1}$, was even higher than ca. $5.5 \mu \mathrm{g} \mathrm{L}^{-1}$ (Uye et al. 1987) or ca. $2 \mu \mathrm{g} \mathrm{L}^{-1}$ (Tada et al. 1998), and it should not be assumed that the primary productivity has decreased. Still, seasonal trends of the primary production rate and phytoplankton biomass might be different compared to those from the past, and the environmental factors leading to these trends are of interest, and thus discussed below. To determine which seasonal environmental parameters (i.e., daily PPFD $_{\text {surface, }}$ diffuse attenuation coefficient $(k)$, water temperature, salinity, $\mathrm{DIN}, \mathrm{PO}_{4}-\mathrm{P}$ and $\mathrm{SiO}_{2}-\mathrm{Si}$ ) controlled the photosynthetic parameters (i.e., $F v / F m$, rETR $_{\max }$ and $\alpha)$ and resulting phytoplankton biomass (chl. a) and production $\left(\mathrm{PPR}_{\mathrm{ETR}}\right)$, a principal component analysis (PCA) was conducted using R version 3. 5.1 (R Core Team 2018) based on Wu \& Wang (2007).

\section{A notable phytoplankton bloom and productivity in winter}

In our results, each year started with the highest chlorophyll $a$ peak in January. Such a winter peak has been recognized in Bingo-Nada in the past (Endo 1964). However, in 1979 and 1980, a chlorophyll $a$ maximum was found in October (Uye et al. 1987). Additionally, in 1993 and 1994, Tada et al. (1998) reported chlorophyll $a$ peaks in October. Even in the most recent report, chlorophyll $a$ peaks were found during July to November in a series of monthly surveys conducted from 2004 to 2007 (Kawaguchi \& Takatsuji 2010). Therefore, the chlorophyll $a$ maximum in January in our study seemingly represents a recent trend that was seldom found in the past. Furthermore, the peaks in October observed in the past have become rare in the present. The reason as to why intensive diatom occurrences were observed in January is not clear; however, these occurrences could be related to a trend in winter temperature. Tarutani (2007) reported that there has been an obvious increase in winter temperature in the Seto Inland Sea since the 1980s. Indeed, the average water temperature in January recorded in this study was $11.2 \pm 1.1^{\circ} \mathrm{C}$, which was higher than the $10.9^{\circ} \mathrm{C}$ recorded in January in 1980 (Uye et al. 1987). Another explanation could be fewer predator zooplankton, like copepods, in January (Uye et al. 1987, Uye \& Liang 1998), although these were not monitored in our study.

In the statistical analysis by PCA, winter, which ranged from December to February, could be delineated by the month of January; winter 1 (from November to January) was the period when PPR ${ }_{\text {ETR }}$ increased with an increase in the chlorophyll $a$ concentration, and winter 2 (from January to March) was the period when $\mathrm{PPR}_{\mathrm{ETR}}$ increased while the chlorophyll $a$ concentration decreased. In the PCA shown in Table 1, in the first winter season (winter 1 in Table 1a, November through January), the relatively high factor loading of $\mathrm{PPR}_{\mathrm{ETR}}(0.706)$ was positively correlated with chlorophyll $a$ concentration (0.483), $\alpha$ (0.654) and $F v / F m(0.705)$ in PCl. This depicts well the coordi-

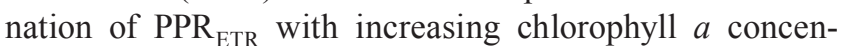
tration. An increase in $\alpha$ was interpreted to represent an increase in the light use efficiency of the phytoplankton population under lower light conditions, as described previously, and may have a large contribution by enabling the phytoplankton population to adapt to the low daily PPFDsurface during this season (Fig. 2d right graph). In fact, the $\alpha$ value was highest in December and January (Fig. $2 \mathrm{~h}$ right graph). Reports of similar increases in $\alpha$ under low light conditions are also found in the literature (Behrenfeld et al. 2004) and were interpreted as a result of low-light acclima- 
Table 1. Factor loadings calculated based on a principal component analysis (PCA) of ETR-based daily primary production rate ( $\left.P P R_{\mathrm{ETR}}\right)$, chlorophyll $a$ concentration (chl. $a$ ), monthly averaged daily value of photosynthetic photon flux density below the sea surface (PPFD surface ), diffuse attenuation coefficient $(k)$, photosynthetic parameters $\left(F v / F m, \mathrm{rETR}_{\max }\right.$ and $\alpha$ ), water temperature (temperature), salinity, DIN, $\mathrm{PO}_{4}-\mathrm{P}$ and $\mathrm{SiO}_{2}-\mathrm{Si}$. Factor loadings of principal component (PC) 1 and PC2 are shown. See the text for the months each corresponding to (a) winter 1, (b) winter 2, (c) spring, (d) summer and (e) autumn.

\begin{tabular}{|c|c|c|c|c|c|c|c|c|c|c|}
\hline & \multicolumn{2}{|c|}{ (a) winter 1} & \multicolumn{2}{|c|}{ (b) winter 2} & \multicolumn{2}{|c|}{ (c) spring } & \multicolumn{2}{|c|}{ (d) summer } & \multicolumn{2}{|c|}{ (e) autumn } \\
\hline & $\mathrm{PC} 1$ & PC2 & PC1 & PC2 & PC1 & PC2 & PC1 & PC2 & PC1 & PC2 \\
\hline $\mathrm{PPR}_{\mathrm{ETR}}$ & 0.706 & 0.415 & 0.198 & 0.110 & 0.591 & 0.317 & 0.187 & 0.623 & 0.690 & 0.473 \\
\hline $\operatorname{chl} . a$ & 0.483 & $<0.1$ & -0.659 & -0.495 & 0.553 & $<0.1$ & 0.181 & 0.290 & 0.825 & 0.144 \\
\hline $\mathrm{PPFD}_{\text {surface }}$ & -0.286 & 0.615 & 0.614 & 0.135 & 0.441 & -0.743 & -0.244 & $<0.1$ & $<0.1$ & 0.273 \\
\hline$k$ & 0.106 & 0.273 & -0.751 & -0.419 & 0.467 & -0.318 & $<0.1$ & -0.145 & 0.404 & -0.356 \\
\hline$F v / F m$ & 0.705 & 0.560 & -0.779 & 0.203 & 0.748 & 0.567 & 0.496 & 0.773 & 0.844 & 0.132 \\
\hline $\mathrm{rETR}_{\max }$ & 0.471 & 0.675 & -0.405 & 0.459 & 0.605 & 0.601 & 0.369 & 0.707 & 0.806 & $<0.1$ \\
\hline$\alpha$ & 0.654 & 0.585 & -0.583 & 0.331 & 0.607 & 0.633 & 0.441 & 0.754 & 0.796 & 0.155 \\
\hline temperature & -0.807 & 0.264 & -0.183 & 0.484 & 0.579 & -0.682 & -0.833 & 0.376 & $<0.1$ & 0.693 \\
\hline salinity & 0.524 & -0.520 & 0.711 & 0.533 & -0.403 & $<0.1$ & 0.382 & -0.323 & -0.523 & 0.603 \\
\hline DIN & -0.520 & 0.503 & -0.489 & 0.705 & 0.691 & -0.565 & 0.767 & -0.243 & 0.110 & -0.727 \\
\hline $\mathrm{PO}_{4}-\mathrm{P}$ & -0.808 & 0.386 & -0.178 & 0.824 & -0.207 & 0.298 & -0.656 & 0.295 & $<0.1$ & -0.705 \\
\hline $\mathrm{SiO}_{2}-\mathrm{Si}$ & -0.834 & 0.271 & -0.584 & $<0.1$ & 0.379 & $<0.1$ & -0.887 & 0.370 & 0.329 & -0.629 \\
\hline var. (\%) & 37.65 & 21.34 & 30.65 & 20.90 & 29.36 & 22.61 & 27.95 & 22.41 & 31.00 & 23.01 \\
\hline cum. (\%) & 37.65 & 58.99 & 30.65 & 51.55 & 29.36 & 51.98 & 27.95 & 50.36 & 31.00 & 54.01 \\
\hline
\end{tabular}

tion in phytoplankton populations.

The chlorophyll $a$ peak in January was caused not only by the ability to cope with low light conditions but also by the high inorganic nutrient levels in December. These high nutrient levels, particularly $\mathrm{PO}_{4}-\mathrm{P}$ and $\mathrm{DIN}$, which were supplied from the anoxic bottom layers in July and August and/or from increased inputs of riverine water in both September and October, were maintained in the water columns throughout winter, especially in December (Fig. 3e and 3f). Based on that $F v / F m$ is an indicator of nutrient stress (Cleveland \& Perry 1987, Higo et al. 2017), it was assumed that these rich nutrient levels led to the highest $F v / F m$ values in December and January (Fig. $2 \mathrm{f}$ right graph), indicating the phytoplankton population was active, and initiated the January chlorophyll $a$ peaks. This explanation was well-supported by the PCA (Table 1a, winter 1, PC1), in which the factor loading of chl. $a(0.483)$ had high correlations with $F v / F m$ (0.705).

The diatom Coscinodiscus wailesii was the most abundant phytoplankton taxon in January, except for in 2015 (when Skeletomena spp. was the most dominant taxon, followed by $C$. wailesii). When considering the temperature range suitable for $C$. wailesii growth $\left(20 \sim 25^{\circ} \mathrm{C}\right)(\mathrm{Ni}-$ shikawa et al. 2000), January is not necessarily suitable for its blooming, though a recent winter temperature rise might improve the chances for the diatom to dominate in January. Nishikawa et al. (2004) reported that C. wailesii increased in October-November and February and caused mass consumption of nutrients in the Harima-Nada area, which is located in the eastern Seto Inland Sea. Probably because a similar phenomenon occurred in our study area, the blooming in January caused remarkable drops in nutrients, as seen in the contour graphs (Fig. $3 \mathrm{e}-\mathrm{g}$ ) as well as leading to significant negative loadings in the PCA analysis for DIN (-0.520), $\mathrm{PO}_{4}-\mathrm{P}(-0.808)$ and $\mathrm{SiO}_{2}-\mathrm{Si}(-0.834)$ as shown in Table 1a (winter 1, PC1).

Since the January bloom, the second winter season (winter 2 in Table 1b), the factor loading of $\operatorname{PPR}_{\text {ETR }}(0.198)$ was too low to indicate a statistical relationship with other parameters, but it correlated positively with daily $\mathrm{PPFD}_{\text {surface }}$ (0.614), indicating increasing daily PPFD $_{\text {surface }}$ after January (Fig. $2 \mathrm{~d}$ right graph) promoted $\mathrm{PPR}_{\mathrm{ETR}}$, a trend similarly found in the surveys of the 1980s and 1990s (Uye et al. 1987, Tada et al. 1998). The factor loading of PPR ETR $_{\text {was }}$ also negatively correlated with chl. $a(-0.659), k(-0.751)$, $F v / F m(-0.779)$, rETR $_{\max }(-0.405)$ and $\alpha(-0.583)$ in PC1. Likewise, there was a negative correlation between $P_{P R} R_{E T R}$ and the chlorophyll $a$ concentration, a correlation only found in this season. Such a unique phenomenon could be attributed to a decrease in the phytoplankton population that led to a decrease in the diffuse attenuation coefficient, as indicated by the strongly positive correlation between chlorophyll $a$ concentration (factor loading: -0.659 ) and $k(-0.751)$ in PC1 of Table $1 \mathrm{~b}$, and this further enhanced light penetration through the water column in this lowPPFD $_{\text {surface }}$ season, which caused a higher PPR ETR $_{\text {. }}$.

\section{Notable phytoplankton blooming in winter caused lowest phytoplankton biomass and drops of $\mathrm{PPR}_{\mathrm{ETR}}$ in spring}

The January bloom, mostly consisting of C. wailesii, and the resulting the nutrient depletions further led to decreases in photosynthetic parameters $\left(F v / F m\right.$ and $\mathrm{rETR}_{\max }$, 
(a) Monthly total precipitation in Fukuyama City, Hiroshima

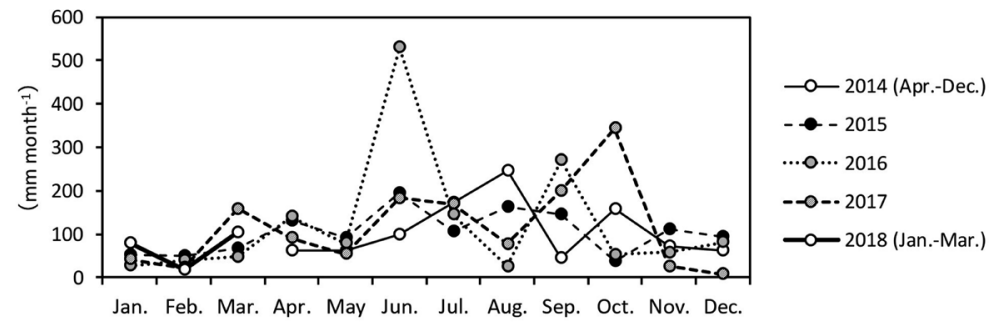

(b) Monthly average amount of water passing through the Ashida River weir

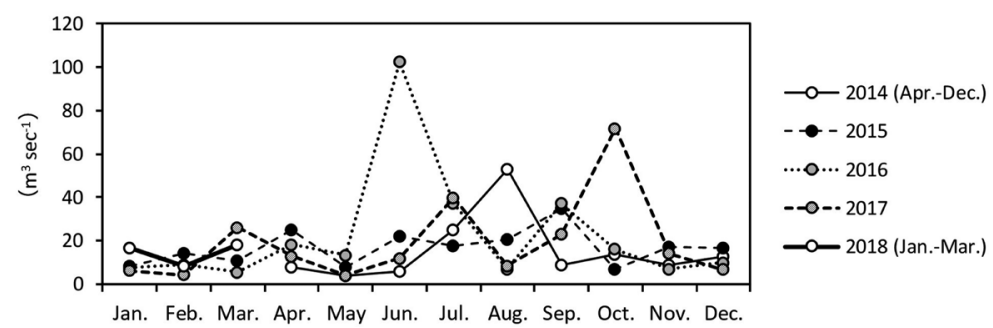

Fig. 7. (a) Monthly total precipitation in Fukuyama City, Hiroshima, and (b) monthly average amount of water passing through the Ashida River weir from April 2014 to March 2018.

Fig. $2 f$ and $2 \mathrm{~g}$ right graph) in April, finally reaching the lowest chlorophyll $a$ levels and drops in $\mathrm{PPR}_{\mathrm{ETR}}$, as outlined in the Results section.

In the PCA of spring (Table 1c), a relatively high value of factor loading (0.591) of PPR $\mathrm{ETR}_{\mathrm{ER}}$ in $\mathrm{PC} 1$ positively correlates with relatively higher factor loadings of the chlorophyll $a$ concentration $(0.553)$, daily $\operatorname{PPFD}_{\text {surface }}(0.441)$, $F v / F m(0.748)$, rETR $_{\max }(0.605)$ and DIN (0.691). This indicates that the environmental variations that primarily influenced PPR ${ }_{\mathrm{ETR}}$, namely, increases in the chlorophyll $a$ concentration, daily PPFD $_{\text {surface }}$ and photosynthetic parameters, were accompanied by increasing DIN, and this element was the principal component controlling the production in spring. This is further evidenced by the two highest values of the factor loadings of $F v / F m(0.748)$ and DIN (0.691) indicating that the DIN level was the limiting factor controlling photosynthesis in spring. Because the factor loading of salinity $(-0.403)$ was strongly negatively correlated with increases in DIN, riverine water was the only source transporting DIN to the area, and this action seemed to be lower in the spring as well as in the previous season. In fact, DIN levels were lowest in March and April (Fig. 3e). A weak but positive factor loading of $\mathrm{SiO}_{2}-\mathrm{Si}(0.379)$ implied $\mathrm{SiO}_{2}-\mathrm{Si}$ was also one of the limiting factors, as suggested from the higher N/Si ratios found during January to March (Fig. 4b). Although this was not evidenced by the PCA because of insignificant factor loading of $\mathrm{PO}_{4}-\mathrm{P}(-0.207)$, probably due to its extremely low concentrations near the detection limit $(0.06 \mu \mathrm{M})$, the level of $\mathrm{PO}_{4}-\mathrm{P}$ was also lowest in March and April (Fig. 3f), and thus it would also probably be a limiting factor for phytoplankton growth.

In connection with the recent January blooming that was not found in the 1970s through the 1990s, this spring minimum has not been previously recognized. However, in Bisan-Seto (Bisan Strait), from April 2012 to March 2013, primary production during the spring season similarly exhibited a minimum value in April, which was attributed to DIN depletion in April that lowered the photosynthetic yield versus light (Yamaguchi et al. 2015). In addition to phytoplankton consumption, low riverine inflow in winter accelerated nutrient depletion. Meteorological data in Fukuyama City (Japan Meteorological Agency 2019) obtained from 2014 to 2018 showed remarkably low precipitation during January through May (19.0 159.0 $\mathrm{mm} \mathrm{month}^{-1}$, mean $=71.2 \mathrm{~mm} \mathrm{month}^{-1}$ ) compared to June to December $\quad\left(75 \sim 530.5 \mathrm{~mm} \mathrm{month}^{-1}, \quad\right.$ mean $\left.=138.5 \mathrm{~mm} \mathrm{month}^{-1}\right)$; consequently, the inflow rate from the Ashida River weir in January through May (mean $=11.4 \mathrm{~m}^{3} \mathrm{sec}^{-1}$ ) was less than half that from June to October $\left(23.4 \mathrm{~m}^{3} \mathrm{sec}^{-1}\right.$ ) (Fig. 7) (Fukuyama River and National Highway Office 2019). The mean precipitation from January to May 2014 2018, $71.2 \mathrm{~mm} \mathrm{month}^{-1}$, was lower than that during 1942 1994 $\left(76.6 \mathrm{~mm} \mathrm{month}^{-1}\right)$, indicating total precipitation in spring has been decreasing recently, although the change is not obvious.

\section{The highest primary production rate in summer}

The next season, summer (June through August), was the most productive season; PPR $_{\mathrm{ETR}}$ was highest in August and was second and third highest in July and June, respectively (Fig. 2b right graph). The season was characterized

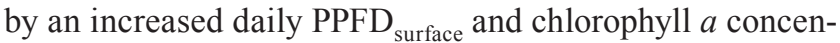
tration (Fig. 2a and 2d right graph), with the peak $P_{P R} R_{E T R}$ found after May (Fig. 2b left graph). In Table 1d, contributions of daily PPFD $_{\text {surface }}$ and chlorophyll $a$ concentration were not clear because of their constantly high values during this season; however, the relatively higher factor 


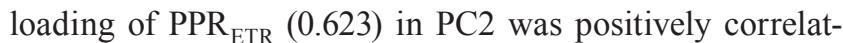
ed with the photosynthetic parameters $F v / F m(0.773)$ and $\mathrm{rETR}_{\max }(0.707)$, which began to increase from their minimum values in April and peaked in July (Figs. 2f-h right graph). Factors possibly leading to these increases were unclear; the photosynthetic parameters were weakly positively correlated with $\mathrm{PO}_{4}-\mathrm{P}(0.295)$ and $\mathrm{SiO}_{2}-\mathrm{Si}(0.370)$. The DIN level was seemingly unrelated to or weakly negatively correlated with photosynthesis or $\mathrm{PPR}_{\mathrm{ETR}}$, based on its negative value $(-0.243)$ in Table 1d (summer, PC2).

As already indicated in the Results, in July and August, $\mathrm{PO}_{4}-\mathrm{P}$ increased mainly in the deep layers (Fig. 3f, arrows) due to excretion in the near-bottom ocean layer, which often causes anoxic conditions (Fig. 3d, arrows) in stratified water (Fig. 3a-c). Under these sufficient $\mathrm{PO}_{4}-\mathrm{P}$ levels in the bottom layers (Fig. 3f), dinoflagellates and raphidophytes could take the place of diatoms, because they migrate vertically and take up nutrients remaining in the bottom layer (Koizumi et al. 1996). The lower N/P ratios temporarily found in the deeper layers in July and August (Fig. 4a) might be favorable to dinoflagellates, which prefer a lower N/P ratio (Kremp et al. 2008). Actually, from May to August, flagellates, which consisted of dinoflagellates, raphidophytes and silicoflagellates, dominated, comprising over $70 \%$ of the total phytoplankton population (Fig. 5 ), and this percent was much higher than that of diatoms $(23.6 \%)$. Diatoms are regarded as the main primary producers affecting coastal primary productivities (more than $90 \%$, Nelson et al. 1995), and the value of $23.6 \%$ in our study was seemingly very low.

The second reason for the flagellates' dominance over diatoms is that the nutrient depletion in spring might have caused diatoms to enter senescence, resulting in flagellate dominance. Generally, centric diatoms dominate more in higher nutrient conditions, and dinoflagellates or raphidophytes dominate in lower nutrient concentration conditions (Menzel et al. 1963). While the conditions leading to silicoflagellate dominance have not yet been adequately investigated, the dominance of $V$. globosus in May might have a similar cause. Cases in May well depicted competition between diatoms and V. globosus. In May 2014, V. globosus dominated and comprised $38.9 \%$ of all phytoplankton, while the contribution of diatoms was limited to $3.7 \%$. Another explanation for the flagellates' dominance is that diatoms prefer lower temperatures than flagellates in general (Karentz \& Smayda 1984). It is known that sea surface water temperature from May to September in the Seto Inland Sea has increased after the 1990s (Kono \& Zenitani 2008).

Also, it should be noted that various harmful species were the major components of those flagellate populations. In particular, $26.5 \%$ of all phytoplankton from May to July was $V$. globosus, a species reported to be harmful and occasionally causing fish kills (Kawaguchi et al. 2007, Lømsland et al. 2013, Chang \& Mullan 2014). The proportion of raphidophytes from May to August, $35.9 \%$, was also notable. Notorious fish killers, species in the genus Chat- tonella, i.e., C. antiqua, C. marina and C. ovata (Imai et al. 2006), were the major group in those raphidophytes. Dinoflagellates were the second abundant (23.4\%) among the flagellates in summer, and a fish killer K. mikimotoi was the second major dinoflagellate after Ceratium spp.

\section{Lowest primary production in autumn}

Uye et al. (1987) reported there were chlorophyll $a$ and primary production peaks in October 1979. In a survey conducted in 1993 through 1994, the maximum chlorophyll $a$ and primary production rate were also recorded in October (Tada et al. 1998). However, in our study, except for an irregular chlorophyll $a$ peak in October 2016 (Fig. 2a left graph), both chlorophyll $a$ and $\mathrm{PPR}_{\mathrm{ETR}}$ did not exhibit annual peaks in October; rather, $P_{\text {PPR }}{ }_{E T R}$ decreased from summer to autumn (Fig. 2b left graph).

Autumn (September through November) was characterized by relatively a high PPR $_{\text {ETR }}$ in August that notably dropped in September then decreased until November (Fig. $2 \mathrm{~b}$ right graph). Nutrient levels in this season were highest in all years (Fig. $3 \mathrm{e}-\mathrm{g}$ ) because of intensive supplies of $\mathrm{PO}_{4}-\mathrm{P}$ from the bottom layers (Fig. 3f) and the input of DIN due to the increase in riverine inflow (Fig. $3 b$ and 3e), and thus were not the controlling factors. This was also demonstrated by the insignificantly low factor loading values of all nutrient species in PCA (Table 1e, PC1). Rather, a significant decrease of the daily PPFD $_{\text {surface }}$ (Fig. 2d right graph) should be the primary factor lowering the PPR $\mathrm{ETR}_{\mathrm{T}}$ in this season, and September was previously recognized as the transient period from the high-PPFD season in summer to the low-PPFD season in winter. In addition, elevations in the diffuse attenuation coefficient from August to October (Fig. 2e right graph) disturbed the penetration of light through the water column and might have caused a synergetic reduction in the light availability to phytoplankton, which might further cause decreases of the photosynthetic parameters in September (Fig. 2f-h right graph).

To help elucidate the possible cause of the induced water turbidity (i.e., diffuse attenuation coefficient) in the autumn period, scatter plots of the diffuse attenuation coefficient and the chlorophyll $a$ concentration were made (Fig. 8), and the linear relationship between the two factors was evaluated by Pearson's product-moment correlation coefficient (r). The correlation coefficients in spring (March through May), summer (June through August) and winter (December through February) were 0.601, 0.633 and 0.685 $(p<0.0001)$, respectively, and were higher than the average correlation coefficient $(0.565, p<0.0001)$. On the other hand, in autumn (September through November), the coefficient was as low as $0.388(p=0.0014)$, and the slope gave higher diffuse attenuation coefficient values than expected from the actual chlorophyll $a$, indicating that the phytoplankton abundance was not the primary reason causing the high turbidity in autumn. The positive factor loading $(0.404)$ of the autumn $k$ (= diffuse attenuation coefficient) in the PCA analysis (Table 1e, autumn, PC1) and the low- 

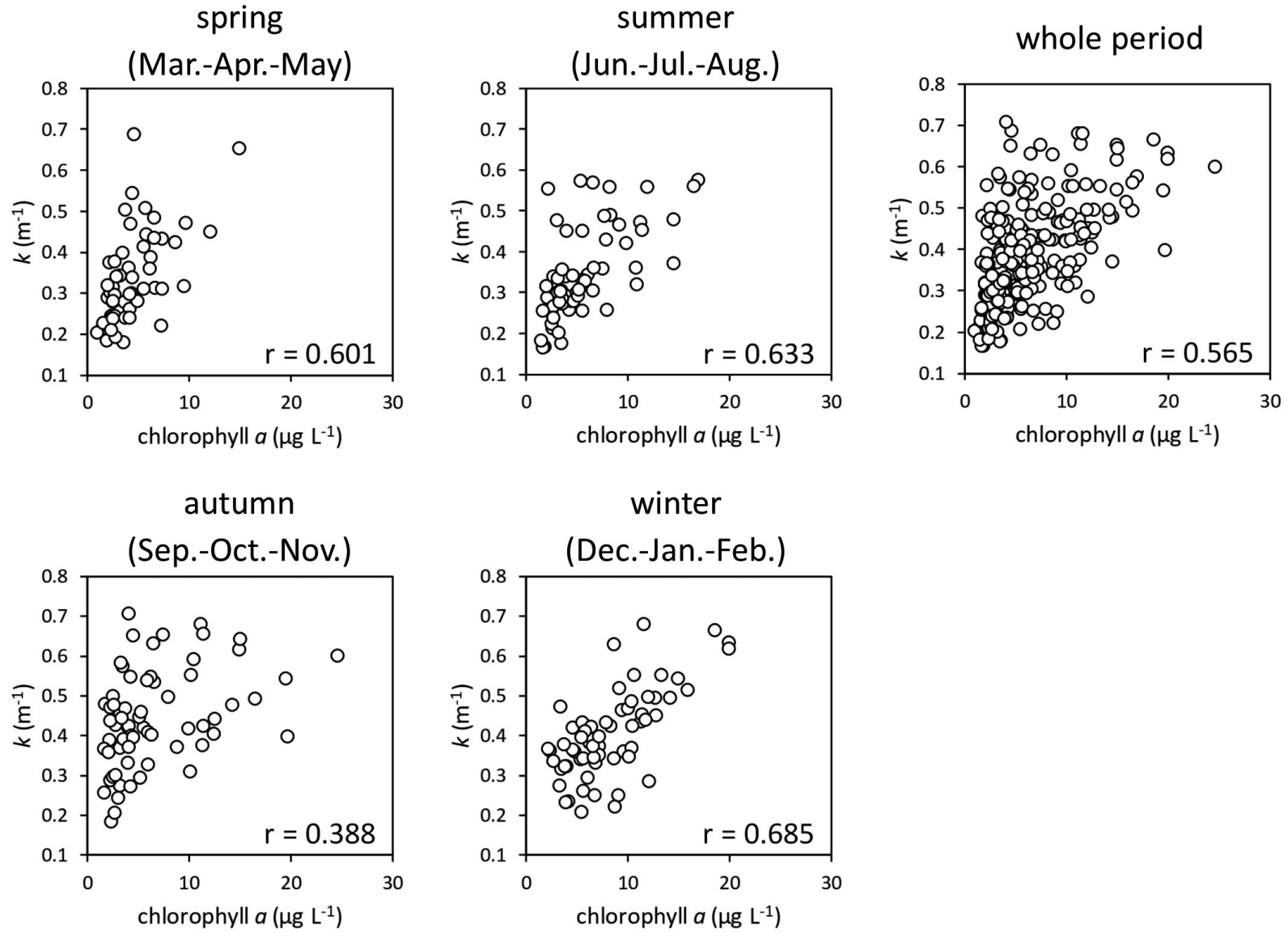

Fig. 8. Scatter plots of the chlorophyll $a$ concentration (chlorophyll $a$ ) versus the diffuse attenuation coefficient ( $k$ ) using data from the whole period (from May 2014 to March 2018). (a) Spring (March through May), (b) summer (June through August), (c) autumn (September through November) and (d) winter (December through February). Values in the lower right corner of each plot indicate Pearson's correlation coefficients (r) between the chlorophyll $a$ and $k$.

est negative value $(-0.523)$ of salinity indicated that the increase in riverine water due to the autumn rain front caused turbidity in the area.

Meanwhile, October might be different from September. After the drops in photosynthesis in September, the average $\mathrm{rETR}_{\max }$ rapidly increased in October and exhibited an annual high (Fig. $2 \mathrm{~g}$ right graph). This was mainly caused by a notable bloom of $C$. wailesii in October 2016 when the highest chlorophyll $a$ peak (Fig. 2a left graph, a dagger) and highest rETR $_{\max }$ (Fig. $2 \mathrm{~g}$ left graph, a dagger) were recorded. It caused the second highest PPR $\mathrm{ETR}_{\text {in }}$ autumn (Fig. 2b left graph, a dagger). C. wailesii was actually a dominant species among the diatoms, occurring every October and making up $48.5-96.5 \%$ (mean $83.7 \pm 23.5 \%$ ) of the total. The water temperature of October, which was still within the suitable range for the growth of this species $\left(20-25^{\circ} \mathrm{C}\right)($ Nishikawa et al. 2000), and the fact that its threshold value of the light level necessary for growth $\left(I_{0}\right), 6.8 \mu \mathrm{mol}$ photons $\mathrm{m}^{-2} \mathrm{sec}^{-1}$ (Nishikawa \& Yamaguchi 2008), was lower than those of other phytoplankton species (Shikata 2016) were seemingly the main causes for its bloom in October.

Unfortunately, we could not clearly demonstrate the true reasons an autumn bloom has not been observed in the past. One of the possibilities was the elevated diffuse attenuation coefficient caused by non-phytoplankton particles, although we could not reach the conclusion that it has indeed increased recently. Rather, turbidity measured at Bingo-Nada in October during 1982-1994 was an average of $3.54 \pm 1.56 \mathrm{ppm}$ and decreased to $2.40 \pm 1.45 \mathrm{ppm}$ in 2014 through 2017 (Ministry of Land, Infrastructure, Transport and Tourism 2019a); the values being affected by phytoplankton particles and therefore having lower values due to phytoplankton density decreases recently. Previous studies reported peaks in October, but phytoplankton species were not mentioned, and therefore the possibility of species transition could not be discussed. Yamaguchi et al. (2015) also reported that primary production in BisanSeto (Bisan Strait) did not show an autumn bloom and constantly decreased from August to December, regardless of the highest photosynthetic yield being in October, and they concluded that the lack of an autumn production peak was attributed not to nutrient (DIN) deficiency but to the high turbidity in Bisan-Seto, where vertical mixing always dominates (Hashimoto et al. 1997). 


\section{The mechanism of primary production: summary}

The most notable phenomenon found in the present study that had not been previously reported was that the highest chlorophyll $a$ peaks occurred in January and were caused by diatoms mainly $C$. wailesii. They occurred abundantly from December, while showing active photosynthesis due to the high levels of nutrients as well as an increased $\alpha$ value that enabled them to adapt to the low light conditions in winter. These rich nutrients, particularly $\mathrm{PO}_{4}-\mathrm{P}$ and DIN, which were intensively supplied from anoxic bottom layers in July and August and/or from increased inputs of riverine water in both September and October, were maintained in the water columns throughout winter, especially in December, until they were consumed by the diatoms. Recent increases of water temperature in the winter season might also have contributed to these prominent occurrences of diatoms. Thereafter, the diatom blooms caused remarkable drops in nutrient concentrations. Although not previously mentioned in the text, discoloration of cultured Nori (Pyropia yezoensis $\mathrm{f}$. narawaensis)-seaweed caused by DIN depletion, empirically under $3 \mu \mathrm{M}$ (Kawaguchi \& Takatsuji 2010), has occurred recently at the study site (Fukuyama City 2015).

The diatom blooms and simultaneous nutrient consumption caused another notable phenomenon in spring: the absence of the so-called "spring bloom". In the PCA, DIN depletion was the principal component limiting the production in spring; however, higher N/Si ratios found during January to March and $\mathrm{PO}_{4}-\mathrm{P}$ levels that were nearly at the detection limit indicated that silicon and phosphorus were also limiting factors that hindered the phytoplankton bloom in spring. The trend of low riverine inflow in winter, somewhat conspicuous in recent years, might also have accelerated nutrient depletion.

Nutrient depletion in spring might have caused diatoms to enter senescence, resulting in flagellate dominances in the following season, starting with dominance of the harmful silicoflagellate, V. globosus, in May. The next season, summer (June through August), was the most productive season because of nutrient resupply in June and increasing $\mathrm{PPFD}_{\text {surface }}$. Photosynthetic parameters of $F v / F m$ and $\mathrm{rETR}_{\max }$, which began to increase from their minimum values in April, peaked in July. However, over $70 \%$ of the total phytoplankton population occurring from May to August was comprised of dinoflagellates, raphidophytes and silicoflagellates. $\mathrm{PO}_{4}-\mathrm{P}$ increased mainly in the deep layers due to excretion in the anoxic bottom water in stratified water, and gave favorable conditions to these flagellate taxa, which migrate vertically and take up nutrients remaining in the bottom layer. Lower N/P ratios were found only during July and August, and recent increases of water temperature since the 1990's might also have promoted their growth over diatoms. Abundant occurrences of notorious fish killers, Chattonella spp., or Karenia mikimotoi, are of concern for local fisheries.
In autumn, chlorophyll $a$ and primary production peaks were observed in past studies but were not obvious in our study, even though nutrient levels, which were derived from intensive supplies of $\mathrm{PO}_{4}-\mathrm{P}$ from the bottom layers and the input of DIN due to the increase in riverine inflow, were high. As well as the $\mathrm{PPFD}_{\text {surface }}$ drop in September, elevations in the diffuse attenuation coefficient from August to October disturbed the penetration of light through the water column and might have caused a synergetic reduction in the light availability to phytoplankton in autumn. Such induced water turbidity (i.e. diffuse attenuation coefficient) in the autumn period was not mainly attributed to phytoplankton abundance but to nonalgal suspended particles that were probably transported from riverine water due to the autumn rain front. However, from October, C. wailesii started to dominate because of its adaptation to the temperature range within October and its lower threshold value for light levels, which enabled it to grow under the senescence light conditions in October. Nonetheless, we could not determine the reasons for a lack of autumn blooms in past studies; however, the decrease in phytoplankton seemed to lead to residual but rich nutrients that continued to occur at high levels until winter, leading into the January diatom bloom.

\section{Acknowledgements}

The authors are grateful to the members of the Tashima fishery cooperative and the crews of the training and research vessel Toyoshiomaru of Hiroshima University for supporting us during sampling. This study was supported by the Japan Fisheries Agency-commissioned project for addressing red tides and oxygen-depleted water masses.

\section{References}

Abo K, Yamamoto T (2019) Oligotrophication and its measures in the Seto Inland Sea, Japan. Bull Jap Fish Res Edu Agen 49: 21-26.

Behrenfeld MJ, Prasil O, Babin M, Bruyant F (2004) In search of a physiological basis for covariations in light-limited and lightsaturated photosynthesis. J Phycol 40: 4-25.

Bricaud A, Babin M, Morel A, Claustre H (1995) Variability in the chlorophyll-specific absorption coefficients of natural phytoplankton: Analysis and parameterization. J Geophys Res Oceans 100: 13321-13332.

Chang FH, Mullan AB (2014) Extended blooms of Karenia concordia and other harmful algae from 2009 to 2011 in Wellington Harbour, New Zealand. In: Proceedings of the 15th International Conference on Harmful Algae. (eds Kim HG, Reguera B, Hallegraeff GM, Lee CK, Han MS, Choi JK), International Society for the Study of Harmful Algae and Intergovernmental Oceanographic Commission of UNESCO, pp. 199-202.

Cleveland JS, Perry MJ (1987) Quantum yield, relative specific absorption and fluorescence in nitrogen-limited Chaetoceros 
gracilis. Mar Biol 94: 489-497.

Endo T (1964) On primary production in Bingo-Nada of Seto Inland Sea I. Primary production and hydrographic condition. J Fac Fish Anim Husb Hiroshima Univ 5: 503-518. (in Japanese) Endo T (1970) On primary production in the Seto Inland Sea. J Fac Fish Anim Husb Hiroshima Univ 9: 177-221. (in Japanese)

Flameling IA, Kromkamp J (1998) Light dependence of quantum yields for PSII charge separation and oxygen evolution in eucaryotic algae. Limnol Oceanogr 43: 284-297.

Fukuyama City (2015) Fukuyama shi suisan shinkou vision [The vision of fishery promotion in Fukuyama City] Available at: http://www.city.fukuyama.hiroshima.jp/soshiki/norinsuisan/ 49246.html (accessed on 30 April 2019) (in Japanese)

Fukuyama River and National Highway Office (2019) Ashidagawa kakouzeki no jyokyo [Amount of inflow, outflow and uptake at the Ashida River weir] Available at: https://www.cgr. mlit.go.jp/fukuyama/river/data/suishitsu-kakouseki.html (accessed on 30 April 2019) (in Japanese)

Geider RJ, Roche J, Greene RM, Olaizola M (1993) Response of the photosynthetic apparatus of Phaeodactylum tricornutum (Bacillariophyceae) to nitrate, phosphate, or iron starvation. J Phycol 29: 755-766.

Geider R, Macintyre, Graziano L, McKay RM (1998) Responses of the photosynthetic apparatus of Dunaliella tertiolecta (Chlorophyceae) to nitrogen and phosphorus limitation. Eur J Phycol 33: 315-332.

Gilbert M, Domin A, Becker A, Wilhelm C (2000) Estimation of primary productivity by chlorophyll $a$ in vivo fluorescence in freshwater phytoplankton. Photosynthetica 38: 111-126.

Goto N, Miyazaki H, Nakamura N, Terai H, Ishida N, Mitamura O (2008) Relationships between electron transport rates determined by pulse amplitude modulated (PAM) chlorophyll fluorescence and photosynthetic rates by traditional and common methods in natural freshwater phytoplankton. Fundam Appl Limnol / Arch für Hydrobiol 172: 121-134.

Hashimoto T, Yamamoto T, Tada K, Matsuda O, Nagasue T (1997) Primary production and physical structure of the Seto Inland Sea. Japan Bull Coast Oceanogr 35: 109-114. (in Japanese with English abstract)

Higo S, Maung-Saw-Htoo-Thaw, Yamatogi T, Ishida N, Hirae S, Koike K (2017) Application of a pulse-amplitude-modulation (PAM) fluorometer reveals its usefulness and robustness in the prediction of Karenia mikimotoi blooms: A case study in Sasebo Bay, Nagasaki, Japan. Harmful Algae 61: 63-70.

Holm-Hansen O, Lorenzen CJ, Holmes RW, Strickland JDH (1965) Fluorometric determination of chlorophyll. ICES J Mar Sci 30: 3-15.

Imai I, Yamaguchi M, Hori Y (2006) Eutrophication and occurrences of harmful algal blooms in the Seto Inland Sea, Japan. Plankton Benthos Res 1: 71-84.

Iriarte A, Daneri G, Garcia VMT, Purdie DA, Crawford DW (1991) Plankton community respiration and its relationship to chlorophyll $a$ concentration in marine coastal waters. Oceanol Acta 14: 379-388.

Japan Meteorological Agency (2019) Kako no data kensaku [Database of the past meteorological data] Available at: www.data. jma.go.jp/obd/stats/etrn/index.php (accessed on 30 April 2019) (in Japanese)
Johnsen G, Sakshaug E (2007) Biooptical characteristics of PSII and PSI in 33 species (13 pigment groups) of marine phytoplankton, and the relevance for pulse-amplitude-modulated and fast-repetition-rate fluorometry. J Phycol 43: 1236-1251.

Karentz D, Smayda TJ (1984) Temperature and seasonal occurrence patterns of 30 dominant phytoplankton species in Narragansett Bay over a 22-year period (1959-1980). Mar Ecol Prog Ser 18: 277-293.

Kawaguchi O, Takatsuji H, Murakami T, Iida Y (2007) Chattonella verruculosa and Chattonella globosa occurred along coastal waters of Hiroshima Prefecture in 2006. Bulletin of the Hiroshima Pref Fisheries \& Marine Technology Center 2: 21-27. (in Japanese)

Kawaguchi O, Takatsuji H (2010) Dynamics of dissolved inorganic nitrogen and its effect on the discoloration of Porphyra yezoensis cultured along the eastern coast of Hiroshima Prefecture, the Seto Inland Sea. Nippon Suisan Gakkaishi 76: 849-854. (in Japanese with English abstract)

Koizumi Y, Uchida T, Honjo T (1996) Diurnal vertical migration of Gymnodinium mikimotoi during a red tide in Hoketsu Bay, Japan. J Plankton Res 18: 289-294.

Kono N, Zenitani H (2008) Distribution of egg production of Japanese anchovy, Engraulis japonicus, in the Seto Inland Sea, Japan, from 1980 to 2005. Nippon Suisan Gakkaishi 74: 636644. (in Japanese with English abstract)

Kovala PE, Larrance JD (1966) Computation of phytoplankton cell numbers, cell volume, cell surface and plasma volume, per liter, from microscopical counts. Department of Oceanography, University of Washington, Special Report 38, Seattle, pp. $1-21$.

Kremp A, Tamminen T, Spilling K (2008) Dinoflagellate bloom formation in natural assemblages with diatoms: nutrient competition and growth strategies in Baltic spring phytoplankton. Aquat Microb Ecol 50: 181-196.

Lippemeier S, Hartig P, Colijn F (1999) Direct impact of silicate on the photosynthetic performance of the diatom Thalassiosira weissflogii assessed by on- and off-line PAM fluorescence measurements. J Plankton Res 21: 269-283.

Lippemeier S, Hintze R, Vanselow K, Hartig P, Colijn F (2001) In-line recording of PAM fluorescence of phytoplankton cultures as a new tool for studying effects of fluctuating nutrient supply on photosynthesis. Eur J Phycol 36: 89-100.

Lømsland E R, Johnsen T M, Eikrem W (2013) Observations on Chattonella globosa in Norwegian coastal waters. In: Proceedings of the 14th International Conference on Harmful Algae (eds Pagou KA, Hallegraeff GM), International Society for the Study of Harmful Algae and Intergovernmental Oceanographic Commission of UNESCO, pp. 126-128.

MaungSaw-Htoo-Thaw, Ohara S, Matsuoka K, Yurimoto T, Higo S, Khin-Ko-Lay, Win-Kyaing, Myint-Shwe, Sein-Thaung, YinYin-Htay, Nang-Mya-Han, Khin-Maung-Cho, Si-Si-Hla-Bu, Swe-Thwin, Koike K (2017) Seasonal dynamics influencing coastal primary production and phytoplankton communities along the southern Myanmar coast. J Oceanogr 73: 345-364.

Menzel DW, Hulburt EM, Ryther JH (1963) The effects of enriching Sargasso Sea water on the production and species composition of the phytoplankton. Deep-Sea Res 10: 209-219.

Ministry of Land, Infrastructure, Transport and Tourism (2019a) 
Setonaikai sougou suishitsu tyousa [Survey for physicochemical and biological parameters in the Seto Inland Sea] Available at: http://www.pa.cgr.mlit.go.jp/chiki/suishitu/index.html (accessed on 28 November 2019) (in Japanese)

Ministry of Land, Infrastructure, Transport and Tourism (2019b) National Land Numerical Information download service. Available at: http://nlftp.mlit.go.jp/ksj/ (accessed on $10 \mathrm{Sep}$ tember 2019) (in Japanese)

Morelle J, Schapira M, Orvain F, Riou P, Lopez PJ, PierreDuplessix O, Rabiller E, Maheuz F, Simon B, Claquin P (2018) Annual phytoplankton primary production estimation in a temperate estuary by coupling PAM and carbon incorporation methods. Estuaries Coasts 41: 1337-1355.

Napoléon C, Claquin P (2012) Multi-parametric relationships between PAM measurements and carbon incorporation, an in situ approach. PLoS One 7: e40284.

Napoléon C, Raimbault V, Claquin P (2013) Influence of nutrient stress on the relationships between PAM measurements and carbon incorporation in four phytoplankton species. PLoS One, 8: e66423.

Nelson DM, Tréguer P, Brzezinski MA, Leynaert A, Quéguiner B (1995) Production and dissolution of biogenic silica in the ocean: revised global estimates, comparison with regional data and relationship to biogenic sedimentation. Global Biogeochem Cycles 9: 359-372.

Nishikawa T, Miyahara K, Nagai S (2000) Effects of temperature and salinity on the growth of the giant diatom Coscinodiscus wailesii isolated from Harima-Nada, Seto Inland Sea, Japan. Nippon Suisan Gakkaishi 66: 993-998. (in Japanese with English abstract)

Nishikawa T, Hori Y (2004) Effects of nitrogen, phosphorus and silicon on a growth of a diatom Coscinodiscus wailesii causing Porphyra bleaching isolated from Harima-Nada, Seto Inland Sea, Japan. Nippon Suisan Gakkaishi 70: 872-878. (in Japanese with English abstract)

Nishikawa T, Yamaguchi Y (2008) Effect of temperature on light-limited growth of the harmful diatom Coscinodiscus wailesii, a causative organism in the bleaching of aquacultured Porphyra thalli. Harmful Algae 7: 561-566.

Nixon SW (1988) Physical energy inputs and the comparative ecology of lake and marine ecosystems. Limnol Oceanogr 33: 1005-1025.

Parsons TR, Takahashi M, Hargrave B (1984) Biological Oceanographic Processes 3rd Edition. Butterworth-Heinemann, Oxford. (Takahashi M, Furuya K, Ishimaru T (1996) Biological Oceanographic Processes 3rd Edition 2, Ryujyou bushitsu no ichiji seisei [Primary generation of granular materials], Tokai University Press, Kanagawa, p. 101. (in Japanese))

Platt T, Gallegos CL, Harrison WG (1980) Photoinhibition of photosynthesis in natural assemblages of marine phytoplankton. J Mar Res 38: 687-701.

R Core Team (2018) R: a language and environment for statistical computing. R Foundation for Statistical Computing, Vienna, Austria. Available at: https://www.R-project.org/ (accessed on 14 June 2018)

Schlitzer R (2018) Ocean Data View. Available at: https://odv. awi.de (accessed on 27 June 2018)

Schreiber U, Schliwa U, Bilger W (1986) Continuous recording of photochemical and non-photochemical chlorophyll fluorescence quenching with a new type of modulation fluorometer. Photosynth Res 10: 51-62.

Setonaikai Fisheries Coordination Office (2018a) Setonaikai no akashio [Red tide in the Seto Inland Sea] Available at: http:// www.jfa.maff.go.jp/setouti/akasio/index.html (accessed on 10 September 2019) (in Japanese)

Setonaikai Fisheries Coordination Office (2018b) Kannai no gyogyou yousyokugyou no gaiyou [Summary of fish catches and aquacultures in Seto Inland Sea.] Available at: http://www.jfa. maff.go.jp/setouti/tokei/ (accessed on 10 September 2019) (in Japanese)

Shelly K, Roberts S, Heraud P, Beardall J (2005) Interactions between UV-B exposure and phosphorus nutrition. I. Effects on growth, phosphate uptake, and chlorophyll fluorescence. J Phycol 41: 1204-1211.

Shikata T (2016) Effects of light on physiological ecology in the red-tide algae. In: Advances in Harmful Algal Bloom Research (eds Imai I, Yamaguchi M, Matsuoka K). Kouseishakouseikaku, Tokyo, pp. 103-109. (in Japanese)

Steemann-Nielsen E (1951) Measurement of the production of organic matter in the sea by means of carbon-14. Nature 167 : 684-685.

Strathmann RR (1967) Estimating the organic carbon content of phytoplankton from cell volume or plasma volume. Limnol Oceanogr 12: 411-418.

Suzuki R, Ishimaru T (1990) An improved method for the determination of phytoplankton chlorophyll using N,N-dimethylformamide. J Oceanogr Soc Japan 46: 190-194.

Tada K, Monaka K, Morishita M, Hashimoto T (1998) Standing stocks and production rates of phytoplankton and abundance of bacteria in the Seto Inland Sea, Japan. J Oceanogr 54: 285-295.

Takami S (2011) Light measurement in Ecological Studies. Clim Bios 11: A1-7. (in Japanese)

Takeoka H (1997) Comparison of the Seto Inland Sea with other enclosed seas from around the world. In: Sustainable development in the Seto Inland Sea. (eds Okaichi T, Yanagi T). Terra Scientific Publishing Company, Tokyo, pp. 223-247.

Tanda M, Akashige S, Ariyama H, Yamanoi H, Kimura H, Dan A, Sakamoto H, Saiki Y, Ishida Y, Kotobuki H, Yamada T (2014) Nutrient environment and fisheries in the Seto Inland Sea. J Fish Tech 7: 37-46. (in Japanese with English abstract)

Tarutani K (2007) Long-term variations in water environments in the Seto Inland Sea of Japan during 1973 to 2002 based on data from the fisheries monitoring program. J J Bento 62: 52-56. (in Japanese with English abstract)

Thimijan RW, Heins RD (1983) Photometric, radiometric, and quantum light units of measure: A review of procedures for interconversion. Hortscience 18: 818-822.

Ueshima H, Hashimoto E, Yamazaki M, Takarada M (1985) Setonaikaisui to gaiyousui no kaisui koukan [Exchange of seawater between the Seto Inland Sea and the open sea.], Proceedings of the 32nd Japanese conference on coastal engineering, pp. 742-746. (in Japanese)

Uye S, Kuwata H, Endo T (1987) Standing Stocks and production rates of phytoplankton and planktonic copepods in the Inland Sea of Japan. J Oceanogr Soc Japan 42: 421-434. 
Uye S, Liang D (1998) Copepods attain high abundance, biomass and production in the absence of large predators but suffer cannibalistic loss. J Mar Syst 15: 495-501.

Wu ML, Wang YS (2007) Using chemometrics to evaluate anthropogenic effects in Daya Bay, China. Estuar Coast Shelf Sci 72: 732-742.

Yamaguchi H, Hirade N, Higashizono K, Tada K, Kishimoto K, Oyama K, Ichimi K (2015) Light and nutrient limitation on phytoplankton production in the strait of an enclosed coastal sea (Bisan Strait, eastern Seto Inland Sea, Japan). J Sea Res 103: $75-83$.
Yamamoto T, Kitamura T, Matsuda O (1996) Riverine inputs of fresh water, total nitrogen and total phosphorus into the Seto Inland Sea. J Fac Appl Biol Sci Hiroshima Univ 35: 81-104. (in Japanese with English abstract)

Yamamoto T (2003) The Seto Inland Sea-eutrophic or oligotrophic? Mar Pollut Bull 47: 37-42.

Yanagi T, Okaichi T (1997) Seto Inland Sea-Historical background. In: Sustainable development in the Seto Inland SeaFrom the Viewpoint of Fisheries. (eds Okaichi T, Yanagi T). Terra Scientific Publishing Company, Tokyo, pp. 9-14. 